\title{
Selective Activation of Estrogen Receptor $\alpha$ Activation Function-1 Is Sufficient to Prevent Obesity, Steatosis, and Insulin Resistance in Mouse
}

\author{
Maeva Guillaume, ${ }^{*}$ Sandra Handgraaf, ${ }^{*}$ Aurélie Fabre, ${ }^{*}$ Isabelle Raymond-Letron, ${ }^{\dagger}$ Elodie Riant, ${ }^{*}$ Alexandra Montagner, ${ }^{*}$ \\ Alexia Vinel, ${ }^{*}$ Melissa Buscato, ${ }^{*}$ Natalia Smirnova, ${ }^{*}$ Coralie Fontaine, ${ }^{*}$ Hervé Guillou, ${ }^{\ddagger}$ Jean-François Arnal, ${ }^{*}$ and \\ Pierre Gourdy ${ }^{\star}$
}

From the Institute of Metabolic and Cardiovascular Diseases (I2MC), * UMR1048, INSERM, UPS, and STROMALab, ${ }^{\dagger}$ CNRS ERL5311, EFS, ENVT, Inserm U1031, UPS, Université de Toulouse, Toulouse; INRA UMR1331, ${ }^{\ddagger}$ ToxAlim, Université de Toulouse III, Toulouse; and the Service de Diabétologie, ${ }^{\S}$ CHU de Toulouse, Toulouse, France

\author{
Accepted for publication \\ February 23, 2017. \\ Address correspondence to \\ Pierre Gourdy, M.D., Ph.D., \\ INSERM UMR1048, Institut \\ des Maladies Métaboliques et \\ Cardiovasculaires, Equipe 9, \\ 1 Ave. Jean Poulhès, BP 84225 , \\ 31432 Toulouse Cedex 4, \\ France. E-mail: pierre. \\ gourdy@inserm.fr.
}

\begin{abstract}
Estrogen receptor $\alpha(E R \alpha)$ regulates gene transcription through two activation functions (ER $\alpha-A F 1$ and $E R \alpha-A F 2)$. We recently found that the protection conferred by $17 \beta$-estradiol against obesity and insulin resistance requires $E R \alpha-A F 2$ but not ER $\alpha-A F 1$. However, the interplay between the two ER $\alpha-A F s$ is poorly understood in vivo and the metabolic influence of a specific ER $\alpha$-AF1 action remains to be explored. To this end, wild-type, ER $\alpha$-deficient, or ER $\alpha$-AF1-deficient ovariectomized female mice were fed a highfat diet and concomitantly administered with vehicle or tamoxifen, a selective ER modulator that acts as a ER $\alpha-A F 1$ agonist/ER $\alpha-A F 2$ antagonist. In ovariectomized wild-type mice, tamoxifen significantly reduced food intake and totally prevented adiposity, insulin resistance, and steatosis. These effects were abolished in ER $\alpha$-deficient and ER $\alpha$-AF1-deficient mice, revealing the specific role of ER $\alpha$-AF1 activation. Finally, hepatic gene expression changes elicited by tamoxifen in wild-type mice were abrogated in ER $\alpha$-AF1-deficient mice. The combination of pharmacologic and transgenic approaches thus indicates that selective ER $\alpha$-AF1 activation by tamoxifen is sufficient to elicit metabolic protection, contrasting with the specific requirement of ER $\alpha-A F 2$ in the metabolic actions of $17 \beta$-estradiol. This redundancy in the ability of the two ER $\alpha$-AFs to separately mediate metabolic prevention strikingly contrasts with the contribution of both ER $\alpha$-AFs in breast cancer proliferation, shedding new light on the therapeutic potential of selective ER modulation. (Am J Pathol 2017, 187: 1273-1287; http://dx.doi.org/10.1016/j.ajpath.2017.02.013)
\end{abstract}

In the past two decades, estrogen receptor $\alpha(\mathrm{ER} \alpha)$ has been identified as a key regulator of energy and glucose homeostasis and consequently proposed as a promising target to develop new therapeutic strategies to fight against obesityrelated metabolic disorders, such as type 2 diabetes and nonalcoholic fatty liver disease. ${ }^{1}$ However, understanding the mechanisms of the metabolic protection conferred by ER $\alpha$ activation remains a crucial challenge for optimizing pharmacologic approaches for selective ER $\alpha$ modulation, especially to avoid or at least to minimize the classic estrogeninduced proliferative effects on reproductive tissues.

As a member of the nuclear receptor superfamily, ER $\alpha$ regulates transcription through two activation functions (AFs) located in the N-terminal (ER $\alpha$-AF1) and C-terminal
(ER $\alpha$-AF2) domains. Both AFs are fully activated by estrogens such as 17 $\beta$-estradiol (E2), although ER $\alpha$-AF1 can also mediate ligand-independent transcriptional activation. $^{2}$

$\mathrm{ER} \alpha-\mathrm{AF} 2$ resides in the well-ordered ligand-binding domain, and crystallographic structures revealed how the

\footnotetext{
Supported by INSERM, Université de Toulouse III, Faculté de Médecine de Toulouse, Fondation de France (J.-F.A.), Conseil Régional MidiPyrénées (J.-F.A., P.G.), Fondation pour la Recherche Médicale (J.-F.A.), Société Francophone du Diabète (P.G.), and Agence Nationale de la Recherche (C.F., H.G., J.-F.A.). The NMR facility is part of the GenotoulIbisa PICT platform and was funded by CNRS, région Midi-Pyrénées and European structural funds.

Disclosures: None declared.
} 
conformational changes induced by various ligands modulate its interactions with conserved motifs of coregulatory proteins. ${ }^{3,4}$ In contrast, ER $\alpha$-AF1, located in the intrinsically disordered $\mathrm{AB}$ domain, has hitherto eluded crystallization and high-resolution structure determinations. ${ }^{5}$ Most steroid hormone receptors are characterized by a relatively large $\mathrm{N}$-terminal domain (400 to 600 amino acids), and AF1 is generally the transcriptional $\mathrm{AF}$ with the highest activity. ${ }^{5}$ However, the ER $\alpha$ N-terminal domain only comprises 184 amino acids, suggesting that $\mathrm{ER} \alpha-\mathrm{AF} 1$ could play a less prominent role compared with ER $\alpha-\mathrm{AF} 2$. Nevertheless, in vitro experiments and the recent generation of mouse models with a selective deletion in either $\mathrm{ER} \alpha-\mathrm{AF} 1$ or $\mathrm{ER} \alpha$ $\mathrm{AF} 2$ revealed that the respective roles of $\mathrm{ER} \alpha-\mathrm{AF} 1$ and $\mathrm{ER} \alpha-\mathrm{AF} 2$ are cell type dependent and even related on differentiation stages. ${ }^{6}$ Indeed, although the activation of both $\mathrm{AFs}$ is required for uterus ${ }^{7}$ and probably also for breast cancer cell proliferation, ${ }^{8-10} \mathrm{ER} \alpha-\mathrm{AF} 2$ activation is required and is sufficient for E2's protection against osteoporosis $^{11}$ and atheroma ${ }^{12-14}$ and also to preserve energy and glucose homeostasis. ${ }^{15}$ Indeed, we recently found that the prevention of high-fat diet (HFD)-induced obesity, insulin resistance, and hyperglycemia by either endogenous estrogens or E2 administration absolutely requires $\mathrm{ER} \alpha-\mathrm{AF} 2$, whereas ER $\alpha$-AF1 appears to be dispensable. ${ }^{15}$

However, the question of whether a pharmacologically selective activation of $\mathrm{ER} \alpha-\mathrm{AF} 1$ retains the ability to confer such a metabolic protection remains to be addressed. Several selective estrogen receptor modulators (SERMs) have been developed for clinical use. Their SERM activity relies on the induction of ligand-specific alterations in the conformation of ER $\alpha$ ligand-binding domain that, thereby, influences the ability of the ER-ligand complex to interact with coactivators and corepressors. ${ }^{3}$ Furthermore, it has been postulated that the relative balance of coactivator and corepressor expression determines the relative agonist versus antagonist activity displayed by SERMs in a specific cellular target. Tamoxifen, the prototypic SERM recognized for $>30$ years as the gold standard for endocrine treatment of ER-positive breast cancer, ${ }^{16}$ has been characterized to exert $\mathrm{ER} \alpha-\mathrm{AF} 1$ agonist and $\mathrm{ER} \alpha-\mathrm{AF} 2$ antagonist effects. ${ }^{7,17}$ Interestingly, although clinical data are scarce regarding the influence of tamoxifen on energy homeostasis and body composition, experimental observations suggested that it could exert a significant protection against body weight gain and adipose tissue accumulation. ${ }^{18,19}$

Thus, to explore the ability of in vivo ER $\alpha$-AF1 selective activation to confer protection against obesity and associated metabolic disorders, we combined the use of tamoxifen, as a pharmacologic tool, with genetically modified mouse models deleted for either the whole $\operatorname{ER} \alpha\left(E R \alpha^{-I-}\right)$ or specifically $\mathrm{ER} \alpha-\mathrm{AF} 1\left(E R \alpha-A F 1^{-/}\right)$. Although experimental data have suggested that the mechanisms of tamoxifen's action and its metabolites could not be restricted to ER $\alpha$ activation, ${ }^{20-22}$ we found that $\mathrm{ER} \alpha$ mediates the tamoxifen-induced prevention of obesity, steatosis, and insulin resistance in HFD-fed ovariectomized female mice. We then found that tamoxifeninduced ER $\alpha-\mathrm{AF} 1$ activation is sufficient to mediate a full protection against HFD-induced dysmetabolic features.

\section{Materials and Methods}

\section{Animals}

Wild-type (WT) C57BL6/J female mice were purchased from Charles River (Saint-Germain-sur-l'Arbresle, France). ER $\alpha$ deficient $\left(E R \alpha^{-/-}\right), \quad \mathrm{ER} \alpha-\mathrm{AF} 1-$ deficient $\left(E R \alpha-A F 1^{-/-}\right)$ mice, and their respective littermates $\left(E R \alpha^{+/+}, E R \alpha-A F 1^{+/+}\right)$, all on a C57BL6/J background, were generated as previously described $^{12}$ and kindly provided by Prof. Pierre Chambon (IGBMC, Strasbourg, France). WT littermates were systematically used as controls. Mice were housed in cages in groups of six and kept in a specific pathogen-free and temperaturecontrolled facility on a 12-hour light to dark cycle. Each experimental group included at least six animals. All procedures that involved experimental animals were performed in accordance with the principles and guidelines established by the Institute National de la Santé et de la Recherche Médicale and were approved by the local ethical committee of animal care.

\section{Treatment and Diet}

All female mice underwent bilateral ovariectomy at 4 weeks of age, and 2 weeks later, they were subcutaneously implanted with pellets releasing either tamoxifen $(1.5 \mathrm{mg}$ for 60 days, ie, $1.2 \mathrm{mg} / \mathrm{kg} / \mathrm{d}$; Innovative Research of America, Sarasota, FL) or vehicle (placebo pellet). The dosage of tamoxifen is in the range of those currently prescribed in clinics and previously reported to exert protective effects on bone, endothelium, and body weight in rodents. ${ }^{18,23-26}$ Mice were concomitantly fed a HFD (energy content: $45 \%$ fat, $20 \%$ protein, and 35\% carbohydrate; $3.7 \mathrm{kcal} / \mathrm{g}$; Research Diets, New Brunswick, NJ) for 6 to 12 weeks.

\section{Experimental in Vivo Procedures}

Mice were anesthetized with $10 \mathrm{mg} / \mathrm{kg}$ i.p. injection of ketamine (Merial, Lyon, France) and $1 \mathrm{mg} / \mathrm{kg}$ xylazine (SigmaAldrich, Isle d'Abeau Chesnes, France) before ovariectomy or with $2 \%$ isoflurane before pellet implantation. Food intake (measurement of food consumption within each cage, expressed as mean weight of food per mice and per day) and body weight were recorded weekly. One week before sacrifice, body composition was analyzed by magnetic resonance imaging (EchoMRI) in live animals. Then i.p. glucose tolerance tests were performed at 9:00 AM after 6 and 12 weeks of treatment in overnight fasted mice. Blood glucose concentrations were monitored with a glucose meter (Roche Diagnostic, Grenoble, France) at $-30,0,30,60$, and 90 minutes after glucose injection $(1 \mathrm{~g} / \mathrm{kg})$. Mice were sacrificed at 11:00 $\mathrm{AM}$, after 3 hours of fasting with free access to water. Blood 
samples were collected from the retro-orbital venous plexus and stored at $-20^{\circ} \mathrm{C}$. Mice were euthanized by cervical dislocation, and organs were carefully removed, weighed, frozen in liquid nitrogen, and stored at $-80^{\circ} \mathrm{C}$.

Determination of Basal Metabolism by Indirect Calorimetry One week before sacrifice, basal metabolism was measured in additional tamoxifen- or vehicle-treated ovariectomized female WT mice fed a HFD for 12 weeks by indirect calorimetry after 24 hours of acclimatization in individual cages. Oxygen consumption, carbon dioxide production, and food and water intakes were measured (Phenomaster; TSE Systems, Bad Homburg vor der Höhe, Germany) in individual mice at 10-minute intervals during a 24-hour period at constant temperature $\left(20^{\circ} \mathrm{C}\right)$. We calculated the respiratory exchange ratio as the ratio of carbon dioxide production to oxygen consumption and energy expenditure (kilocalories of heat produced). Ambulatory physical activity was monitored by an infrared photocell beam interruption method.

\section{Short-Term Pair-Feeding Procedure}

A pair-feeding procedure was performed in ovariectomized WT female mice fed a chow diet and receiving daily s.c. injections of tamoxifen $(0.5 \mathrm{mg} / \mathrm{kg}$, dissolved at a concentration of $0.125 \mathrm{mg} / \mathrm{mL}$ in sesame oil that contained $1 \%$ ethanol; Sigma-Aldrich) or vehicle $(4 \mu \mathrm{L} / \mathrm{g})$ for 5 days. Each day, the vehicle-treated group received a quantity of diet corresponding to the mean amount eaten the day before by tamoxifen-treated animals. Mice were sacrificed 4 hours after the final injection.

\section{Liver Tissue Histology}

Liver tissues were quickly excised, fixed in $10 \%$ buffered formalin, and embedded in paraffin, and sections $(3 \mu \mathrm{m})$ were stained with hematoxylin and eosin (H\&E). Additional fresh liver samples were immersed in Tissue-Tek O.C.T. Compound (Sakura Finetek Japan Co., Ltd., Tokyo, Japan) then frozen in isopentane cooled by liquid nitrogen, and cryosections $(7 \mu \mathrm{m})$ were stained with Oil Red O (ORO) to assess neutral lipid accumulation as previously described with minor modifications. ${ }^{27}$ Images of each sample were obtained with Eclipse Ci Nikon microscope and using DS-FI camera driven by NIS-AR element software version 4.13 (Nikon, Tokyo, Japan) (H\&E sections) or scanned (ORO sections) with nanozoomer scanner (Hamamatsu Photonics, Hamamatsu, Japan) and analyzed with NDP view software version 1.2.47 (Hamamatsu Photonics).

\section{Liver Lipid Content Analysis}

Hepatic levels of triglycerides, free cholesterol, and cholesterol esters were determined using the Bligh and Dyer method, ${ }^{28}$ and lipid extracts were analyzed by gas-liquid chromatography as previously described. ${ }^{29}$

\section{Biochemical Analysis}

Serum samples were used to measure alanine aminotransferase and lipid profile (free fatty acids, triglycerides, total and high-density lipoprotein cholesterol). Plasma insulin and adipokines (resistin, leptin, adiponectin) levels were determined using the Multiplex Immunoassay Technology Xmap (MADKMAG-71K-05 and MADPNMAG-70K-01; Millipex, Millipore, Saint-Quentin-en-Yveline, France). A commercial enzyme-linked immunosorbent assay kit was used to measure serum levels of fibroblast growth factor 21 (EZRMFGF21-26K; Millipore) according to the manufacturer's instructions.

\section{Gene Expression Analysis}

Total mRNA were extracted from homogenized liver and subcutaneous white adipose tissue samples using a Precellys tissue homogenizer (Bertin Technology, Saint-Quentin-enYveline, France) and the GenElute Mammalian Total RNA Miniprep kit (Sigma-Aldrich), then reverse transcribed using the High-Capacity cDNA Reverse Transcription kit (Applied Biosystems, Foster City, CA). For hepatic gene expression profiling in WT mice, we performed a quantitative PCR (Fluidigm Dynamic Array, Fluidigm platform, GenoToul, Toulouse, France) from a set of 42 genes based on published microarrays databases available from https://www.ncbi.nlm. nih.gov/gds (accession numbers GSE70329 and GSE70350) and bibliographic analysis highlighting genes reported to be involved in hepatic lipid and glucose metabolic pathways or sensitive to estrogens. Real-time quantitative PCR was performed using an ABI ViiA 7 apparatus. We then performed real-time quantitative PCR on ABI StepOnePlus (Life Technologie, GeT facility, GenoToul) for a set of hepatic genes regulated by tamoxifen in WT mice to assess hepatic expression changes in ER $\alpha-A F 1$ mice. Similarly, real-time quantitative PCR was performed to evaluate adipose tissue gene expression from a set of eight genes involved in lipid and glucose metabolic pathways. Primers were validated by testing PCR efficiency using standard curves (efficiency, 95\% to 105\%). Primers used in this study are listed in Table 1 . Gene expression was quantified using the comparative $\mathrm{C}_{\mathrm{T}}$ method. Hypoxanthine guanine phosphoribosyl transferase 1 was used as reference.

\section{Statistical Analysis}

Results are expressed as means \pm SEM. Statistical analyses were performed using GraphPad Prism version 5.00 for Windows (GraphPad Software, San Diego, CA; www.graphpad. com). $t$-tests were used to analyze the effects of treatment and genotype on all parameters, except for body weight evolution and i.p. glucose tolerance tests for which two-way analysis of variance tests with repeated measures were used to test the interaction between treatment and genotypes. Bonferroni 
Table 1 Oligonucleotide Sequences for Real-Time PCR

\begin{tabular}{|c|c|c|c|}
\hline Gene & NCBI refseq & Forward primer & Reverse primer \\
\hline Acaa2 & NM_177470 & 5'-AGTCGTGGGCTACTTCGTGTC-3' & 5'-GGCAAAAGCTTCGTTCACGTCT-3' \\
\hline Acaca & NM_133360 & $5^{\prime}$-TTACAGGATGGTTTGGCCTTTC-3' & $5^{\prime}$-CAAATTCTGCTGGAGAAGCCAC- $3^{\prime}$ \\
\hline Acacb & NM_133904 & $5^{\prime}$-CCTGAATCTCACGCGCCTA-3' & 5'-CAGATGGAGTCCAGACATGCTG-3' \\
\hline Acox1 & NM_015729 & $5^{\prime}-\mathrm{CAAAGAAACCCCTCCAGCC-3^{ \prime }}$ & 5'-GCTGTGTGCCGTCTGGAGT-3' \\
\hline Acadl & NM_007381 & $5^{\prime}$-AGAAGTTCATCCCCCAGATGAC-3' & 5'-GGCGTTCGTTCTTACTCCTTGT-3' \\
\hline Apoa1 & NM_009692 & $5^{\prime}-$ TGGGCCAACAGCTGAACC-3' & 5'-TCCCAGAAGTCCCGAGTCAA-3' \\
\hline Apoa4 & NM_007468 & $5^{\prime}-$ ACCCAGCTAAGCAACAATGCC - $3^{\prime}$ & $5^{\prime}$-GTCCTGGAAGAGGGTACTGAGC- $3^{\prime}$ \\
\hline Apoa5 & NM_080434 & $5^{\prime}-\mathrm{AAGCACTCAGGCACGGAAGAG-3^{ \prime }}$ & 5'-GCTGCCTTTCAGGTTCTCCTGT-3' \\
\hline Apob & NM_009693 & 5'-AATCTGTGGTTTCATCATGAGGAC-3' & 5'-GGCCAGCTTGAGTTCGTACCT-3' \\
\hline Cebpa & NM_007678 & $5^{\prime}$-AGGGACTTAGGTGTTGGGGATT-3' & 5'-GTGCAAAAAGCAAGGGATTAGG-3' \\
\hline Cpt1a & NM_013495 & $5^{\prime}$-GAAGAAGAAGTTCATCCGATTCAAG-3' & $5^{\prime}$-GATATCACACCCACCACCACG-3' \\
\hline Cур17a & NM_007809 & $5^{\prime}-\mathrm{CATCCCACACAAGGCTAACA-3^{ \prime }}$ & $5^{\prime}-\mathrm{CAGTGCCCAGAGATTGATGA-3^{ \prime }}$ \\
\hline Сур7а1 & NM_007824 & $5^{\prime}$-AGAGCAACTAAACAACCTGCCAGTA-3' & 5'-GCACTGGAGAGCCGCAGA-3' \\
\hline Dgat2 & NM_026384 & 5'-ACAGCTGCAGGTCATCTCAGTACTA-3' & 5'-AGCACAGCTATCAGCCAGCA-3' \\
\hline Fabp1 & NM_017399 & $5^{\prime}-$ AAAGTCAAGGCAGTCGTCAAGC - 3' & 5'-CAATGTCGCCCAATGTCATGGT-3' \\
\hline Fabp4 & NM_024406 & $5^{\prime}-\mathrm{AAATCACCGCAGACGACAGGAA-3^{ \prime }}$ & 5'-TGTGGTCGACTTTCCATCCCA-3' \\
\hline Fasn & NM_007988 & 5'-AGTCAGCTATGAAGCAATTGTGGA-3' & $5^{\prime}-\mathrm{CACCCAGACGCCAGTGTTC-3^{ \prime }}$ \\
\hline Fgf21 & NM_020013 & 5'-AAAGCCTCTAGGTTTCTTTGCCA-3' & $5^{\prime}$-CCTCAGGATCAAAGTGAGGCG-3' \\
\hline G6pc & NM_008061 & $5^{\prime}$-СTCACTTTCCCCACCAGGTC-3' & $5^{\prime}$-GCTGAAAGTTTCAGCCACAGC-3' \\
\hline Gdf15 & NM_011819 & 5'-TGGGACCCCAATCTCACCTCT-3' & $5^{\prime}$-AGCCGAGAGGACTCGAACTCA-3' \\
\hline Gck & NM_010292 & $5^{\prime}-$ TCGCAGGTGGAGAGCGA $-3^{\prime}$ & $5^{\prime}-$ TCGCAGTCGGCGACAGA-3' \\
\hline Hprt & NM_013556 & 5'-ACAGGCCAGACTTTGTTGGATT-3' & 5'-TTGCGCTCATCTTAGGCTTTGT-3' \\
\hline $\mathrm{Hmgcr}$ & NM_008255 & 5'-CTTGTGGAATGCCTTGTGATTG-3' & 5'-GAAGAATGTCATGAACACAAAGTAGTTG-3 \\
\hline Insr & NM_010568 & $5^{\prime}$-CACTGTCATCAATGGGCAGTTT-3' & $5^{\prime}$-CATCAGGTTCCGAACAGTTGC-3' \\
\hline Irs2 & NM_001081212 & 5'-GGAGCCGGACCCGTAGCCTT-3' & 5'-GGCTGGTAGCGCTTCACTCTTTC-3' \\
\hline Lep & NM_008493 & 5'-CAGTGCCTATCCAGAAAGTCCAG-3' & 5'-AATGAAGTCCAAGCCAGTGACC-3' \\
\hline Lepr & NM_146146 & 5'-АTTCCCTCGGCGCTTCCCTT-3' & $5^{\prime}$-ACAGCTGCTGCTCAGGGGAT-3' \\
\hline$L p l$ & NM_008509 & $5^{\prime}-\mathrm{ATGGCAAGCAACACAACCAG-3^{ \prime }}$ & $5^{\prime}-$ TGTGGAAACCTCGGGCAG- $3^{\prime}$ \\
\hline Mlxipl & NM_021455 & $5^{\prime}-$ ACTCAGGGAATACACGCCTACAG- $3^{\prime}$ & $5^{\prime}$-GAAGAAGGAATTCAGAGCTCAGAAA-3' \\
\hline Nr1h3 & NM_013839 & 5'-GGAGTGTCGACTTCGCAAATG-3' & 5'-TCAAGCGGATCTGTTCTTCTGAC-3' \\
\hline Nr1h4 & NM_009108 & $5^{\prime}-$ CCACCGGCTGTCAGGATT- $3^{\prime}$ & 5'-CGCGTGTTCTGTTAGCATACCTT-3' \\
\hline Pck1 & NM_011044 & $5^{\prime}$-GGCCACAGCTGCTGCAG-3' & $5^{\prime}$-GGTCGCATGGCAAAGGG-3' \\
\hline Pemt & NM_001290012 & $5^{\prime}$-АCTCATGCATGCTAGTCCCA-3' & $5^{\prime}$-AGCAGTGAAGGGCTCTTCAT-3' \\
\hline Pltp & NM_011125 & 5'-GGATTAAAGTGTCCAATGTCTCCTG-3' & 5'-GTGGAGAAAAAGTTATACATCCTCCTG-3' \\
\hline Plin2 & NM_007408 & $5^{\prime}$-ССАТTTCTCAGCTCCACTCCAC-3' & 5'-GTGTCGTCGTAGCCGATGC-3' \\
\hline Pnpla2 & NM_001163689 & 5'-AGTGTCCTTCACCATCCGCTT-3' & 5'-GGATATCTTCAGGGACATCAGGC-3' \\
\hline Ppara & NM_011144 & 5'-CCCTGTTTGTGGCTGCTATAATTT-3' & 5'-GGGAAGAGGAAGGTGTCATCTG-3' \\
\hline Ppard & NM_011145 & $5^{\prime}-\mathrm{AAGTGGCCATGGGTGACG-3^{ \prime }}$ & 5'-TGGTCCAGCAGGGAGGAAG- $3^{\prime}$ \\
\hline Pparg & NM_011146 & 5'-ATGGGTGAAACTCTGGGAGATTCT-3' & 5'-CTTGGAGCTTCAGGTCATATTTGTA-3' \\
\hline Sirt1 & NM_019812 & 5'-GCTGTGAAGTTACTGCAGGAGTGT-3' & 5'-CCGCAAGGCGAGCATAGATA-3' \\
\hline Scd1 & NM_009127 & 5'-CAGTGCCGCGCATCTCTAT-3' & 5'-CTGACTGGCAAATATAGCTGTATCCT-3' \\
\hline Srebf1 & NM_011480 & $5^{\prime}$-CAGACACTGGCCGAGATGTG-3' & 5'-CTTGGTTGTTGATGAGCTGGAG-3' \\
\hline Slc2a4 & NM_009204 & $5^{\prime}-$ AAAAGTGCCTGAAACCAGAG-3' & 5'-TCAССТССТGСТСТАAAAGG-3' \\
\hline Ucp2 & NM_011671 & $5^{\prime}$-CATGGTAGCCACCGGCA-3' & $5^{\prime}$-CTTCAATCGGCAAGACGAGAC- $3^{\prime}$ \\
\hline
\end{tabular}

NCBI refseq, National Center for Biotechnology Information reference sequence.

posttests were subsequently performed in case of interaction. $P<0.05$ was considered statistically significant.

\section{Results}

Tamoxifen Prevents HFD-Induced Metabolic Disorders in WT Female Mice

To first determine whether ER $\alpha$-AF1 pharmacologic activation confers metabolic protection in our experimental settings, ovariectomized WT female mice were fed with a
HFD and concomitantly treated with $1.2 \mathrm{mg} / \mathrm{kg} / \mathrm{d}$ of tamoxifen or vehicle for 12 weeks. As expected, tamoxifen induced a proliferative effect on the uterus with a wet uterine weight of $33.5 \pm 2.8 \mathrm{mg}$ in tamoxifen-treated mice versus $13.0 \pm 2.2 \mathrm{mg}$ in control mice $(P=0.0002)$. Tamoxifen administration prevented HFD-induced body weight gain (Figure 1A), an effect associated with a significant reduction in food intake compared with control mice (Figure 1B). In terms of body composition, tamoxifen prevented HFD-induced fat mass accumulation but did not influence lean mass (Figure 1C). The prevention of fat mass 


\section{A Body weight}

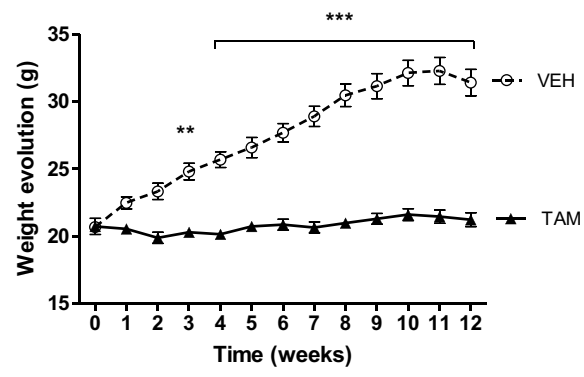

\section{Body composition}

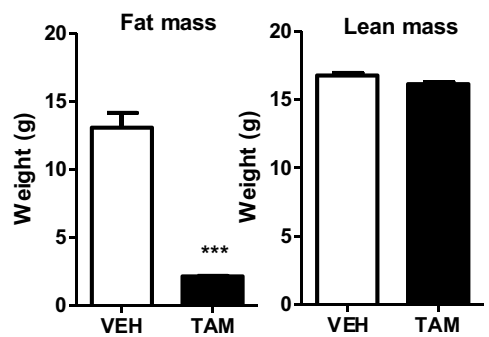

\section{E Glucose tolerance}

HFD 6 weeks

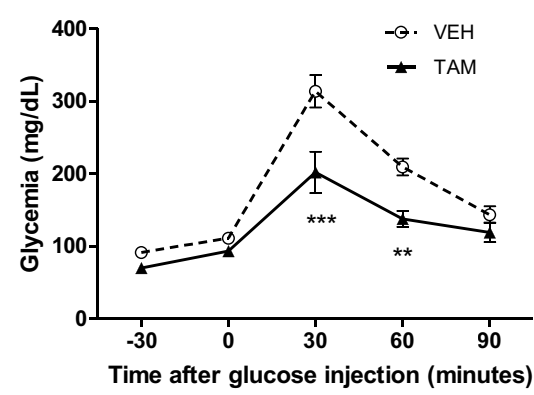

G Intrahepatic lipid content
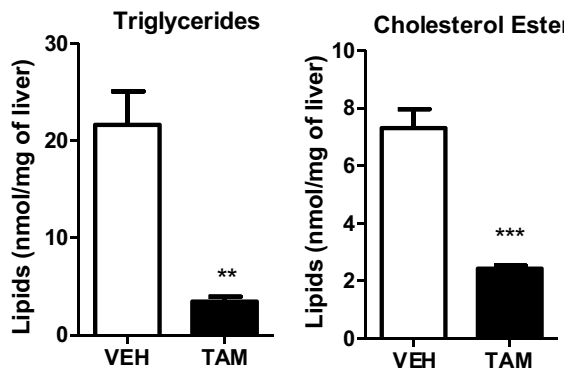

\section{B Food intake}
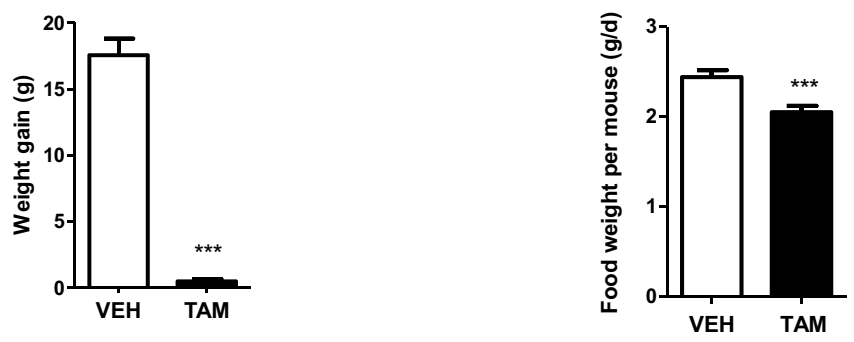

D Adipose tissue distribution
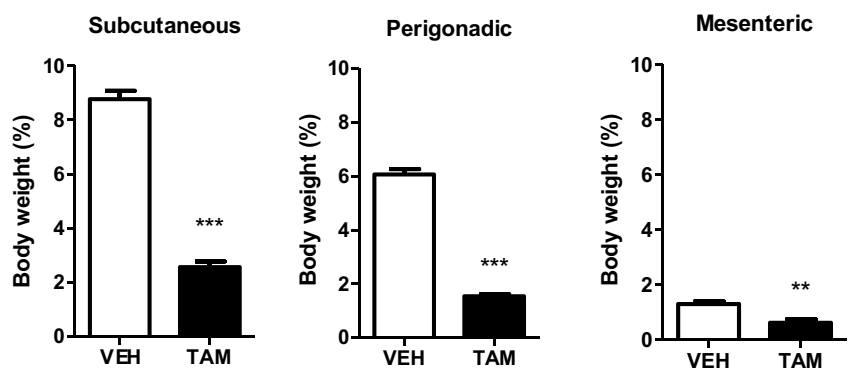

F Insulin resistance

HFD 12 weeks
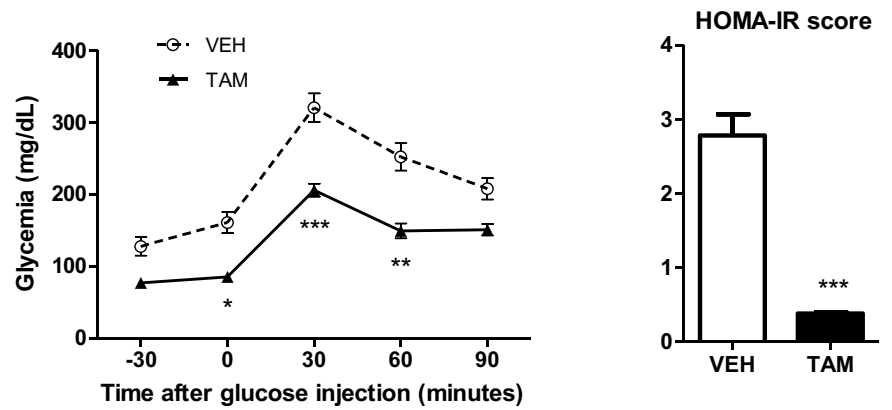

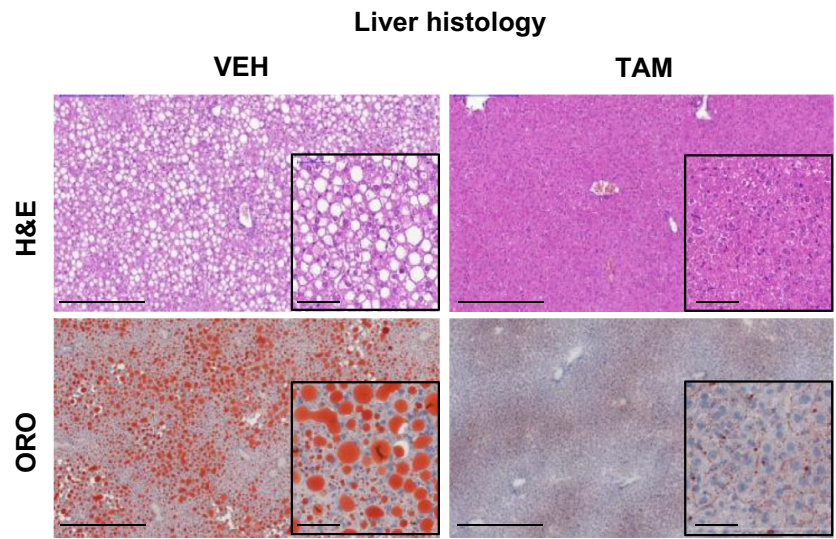

Figure 1 Tamoxifen (TAM) prevents high-fat diet (HFD)-induced metabolic disorders in wild-type (WT) female mice. Ovariectomized WT female mice were fed a HFD and concomitantly treated with TAM or vehicle (VEH) for 12 weeks. A and B: Body weight evolution (A), final body weight gain (A), and food intake (B) were recorded weekly. C: Body composition (fat mass and lean mass) was assessed by magnetic resonance imaging (EchoMRI) after 12 weeks of HFD. D: Adipose tissue distribution (subcutaneous, perigonadic, and mesenteric sites) was assessed at sacrifice. E: i.p. glucose tolerance tests were performed after 6 and 12 weeks of HFD. F: Insulin resistance was estimated by homeostatic model assessment of insulin resistance (HOMA-IR) score, calculated after 12 weeks of HFD. G: Intrahepatic neutral lipid content and liver histology were assessed at sacrifice. Representative images of hematoxylin and eosin (H\&E) and 0il Red 0 (ORO) staining on liver sections. Insets show higher magnification. Data are expressed as means \pm SEM. ${ }^{*} P<0.05,{ }^{*} P<0.01$, and ${ }^{* * *} P<0.001$ (TAM versus VEH). Scale bars: $100 \mu \mathrm{m}(\mathbf{G}) ; 50 \mu \mathrm{m}$ (G, insets). Original magnification, $\times 40$ (insets). 
expansion not only concerned subcutaneous but also visceral (ie, perigonadic and mesenteric) white adipose tissues (Figure 1D).

As respectively attested by glucose tolerance tests (Figure 1E) and homeostatic model assessment of insulin resistance values (Figure 1F), tamoxifen-treated WT mice were also protected from HFD-induced glucose intolerance and insulin resistance, which rapidly occurred in control mice as expected. Moreover, tamoxifentreatment protected WT mice from fatty liver development, as suggested by histologic staining with H\&E and ORO and confirmed by the reduction of intrahepatic triglycerides content compared with vehicle-treated mice (Figure 1G). Tamoxifen also induced a significant decrease in intrahepatic cholesterol ester content (Figure 1G) but did not affect intrahepatic free cholesterol (data not shown). Noteworthy, no sign of hepatotoxicity was observed in tamoxifen-treated mice and especially no increase in plasma alanine aminotransferase levels (Table 2). According to the preservation of liver from steatosis, plasma concentration of the hepatokine fibroblast growth factor 21 was drastically reduced in tamoxifentreated WT mice (Table 2). In addition, we determined whether tamoxifen administration influenced the secretion of the main adipokines and found that adiponectin and leptin plasma levels were strongly reduced in tamoxifentreated mice compared with control mice, whereas plasma resistin concentration was not altered (Table 2). Finally, tamoxifen induced a significant reduction in plasma total cholesterol, high-density lipoprotein cholesterol, and free fatty acids but did not affect low-density lipoprotein cholesterol or triglycerides compared with control mice (Table 2).

Altogether, these results indicate that, as previously described on ovariectomized rats under chow diet, ${ }^{18}$ tamoxifen reduces food intake and protects ovariectomized female mice from HFD-induced metabolic disturbances.
Prevention of Body Weight Gain by Tamoxifen Does Not Result Only from Its Anorectic Effect

To further characterize the mechanisms involved in the prevention of obesity and metabolic disorders by tamoxifen, we then explored the action of this SERM on basal metabolism by indirect calorimetry performed in HFD-fed WT female mice treated with tamoxifen or vehicle for 12 weeks. A significant decrease in oxygen consumption (Supplemental Figure S1A) and carbon dioxide production (Supplemental Figure S1B) was observed in tamoxifen-treated mice, leading to a similar respiratory exchange ratio (Supplemental Figure S1C) compared with control mice. In addition, tamoxifen-treated mice were characterized by significantly reduced physical activity (Supplemental Figure S1D) and energy expenditure levels (Supplemental Figure S1E), which are in accordance with the confirmed decrease in food consumption. Altogether, these results thus suggest that the beneficial metabolic effects of tamoxifen could be mainly attributed to its anorectic action that probably explains the lower basal metabolism level.

However, to address the hypothesis that mechanisms independent from food intake control could also be involved in the prevention of body weight regulation by tamoxifen, a pair-feeding procedure was conducted in ovariectomized female mice receiving daily s.c. injections of either tamoxifen or vehicle for 5 days. As expected, no significant difference in food intake was observed between tamoxifenand vehicle-treated animals (Supplemental Figure S2A), whereas tamoxifen induced its expected proliferative effect on the uterus (Supplemental Figure S2B). Both groups had similar body weight gain (Supplemental Figure S2C), but tamoxifen reduced s.c. and visceral white adipose tissue accumulation (Supplemental Figure S2D) as well as intrahepatic cholesterol ester content (Supplemental Figure S2E) compared with vehicle. These data suggest that beside the

Table 2 Influence of TAM on Plasma Parameters in High-Fat Diet-Fed Wild-Type Mice

\begin{tabular}{lcc}
\hline Parameter & VEH & TAM \\
\hline ALT, IU/L & $70 \pm 24$ & $57 \pm 9$ \\
Total cholesterol, mmol/L & $4.01 \pm 0.22$ & $2.59 \pm 0.20^{* *}$ \\
HDL-C, mmol/L & $1.92 \pm 0.07$ & $1.28 \pm 0.11^{* * *}$ \\
LDL-C, mmol/L & $0.47 \pm 0.03$ & $0.50 \pm 0.03$ \\
Triglycerides, mmol/L & $0.89 \pm 0.04$ & $0.76 \pm 0.06$ \\
Free fatty acids, mmol/L & $0.88 \pm 0.04$ & $0.57 \pm 0.03^{* * *}$ \\
Insulin, ng/mL & $1.40 \pm 0.13$ & $0.40 \pm 0.04^{* * *}$ \\
Resistin, $\mathrm{ng} / \mathrm{mL}$ & $3.25 \pm 0.46$ & $3.82 \pm 0.29$ \\
Adiponectin, ng/mL & $6.27 \pm 0.21$ & $4.71 \pm 0.56^{* * *}$ \\
Leptin, $\mathrm{ng} / \mathrm{mL}$ & $18.52 \pm 1.18$ & $2.26 \pm 0.42^{* * *}$ \\
FGF21, pg/mL & $143 \pm 122$ & $\mathrm{ND}(<10)^{* * *}$ \\
\hline
\end{tabular}

Blood samples from wild-type female mice fed a high-fat diet for 12 weeks and concomitantly treated with TAM or VEH were collected at sacrifice after a 3-hour fasting at 11:00 AM. Data are expressed as means \pm SEM.

$* * P<0.01, * * * P<0.001$ (TAM versus VEH).

ALT, alanine aminotransferase; FGF21, fibroblast growth factor 21; HDL-C, high-density lipoprotein cholesterol; LDL-C, low-density lipoprotein cholesterol; ND, not detectable; TAM, tamoxifen; VEH, vehicle. 


\section{A Body weight}

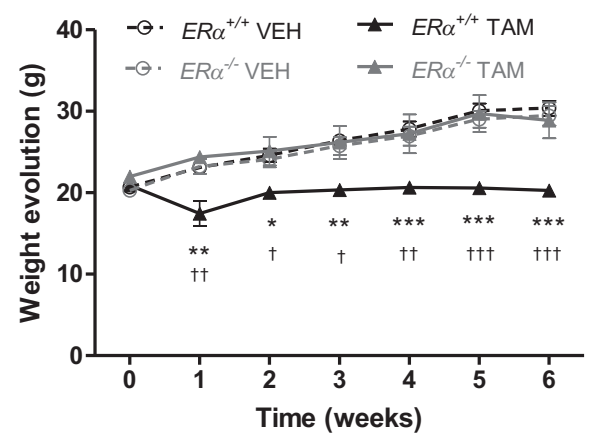

C Body composition

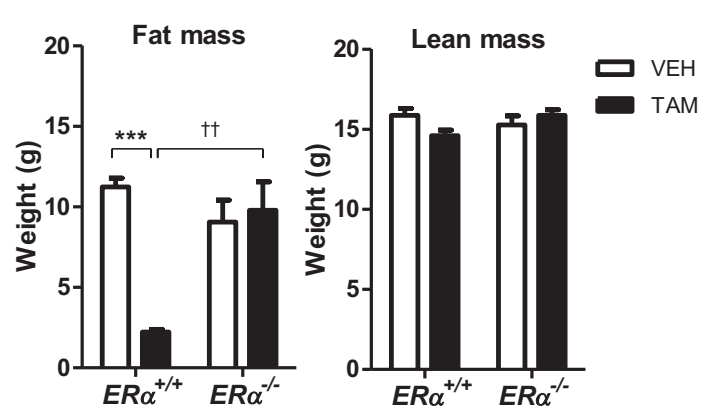

E Glucose tolerance test

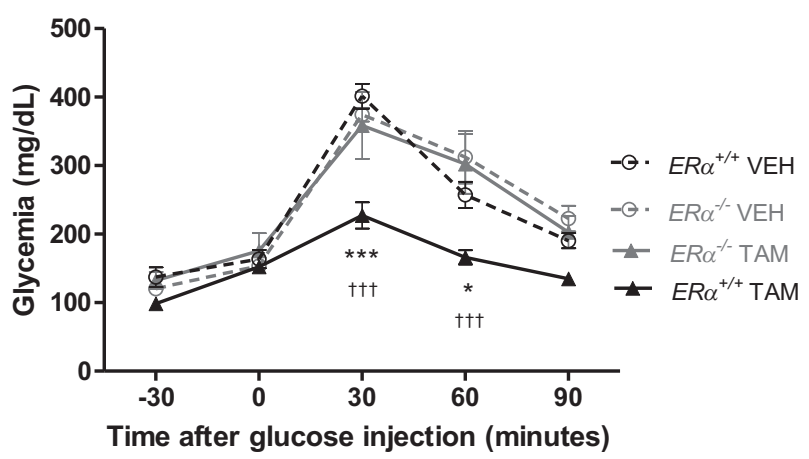

B Food intake

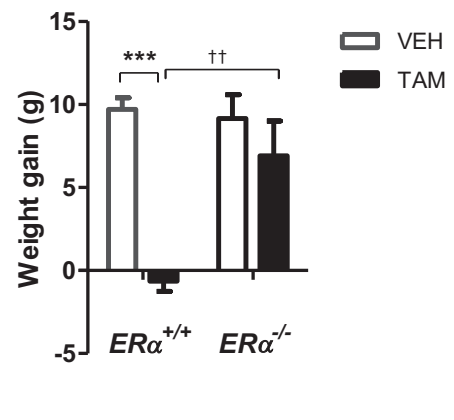

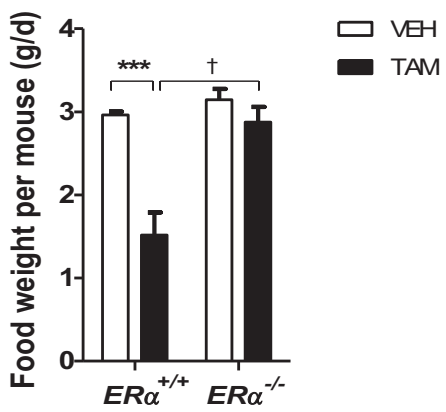

D Adipose tissue distribution
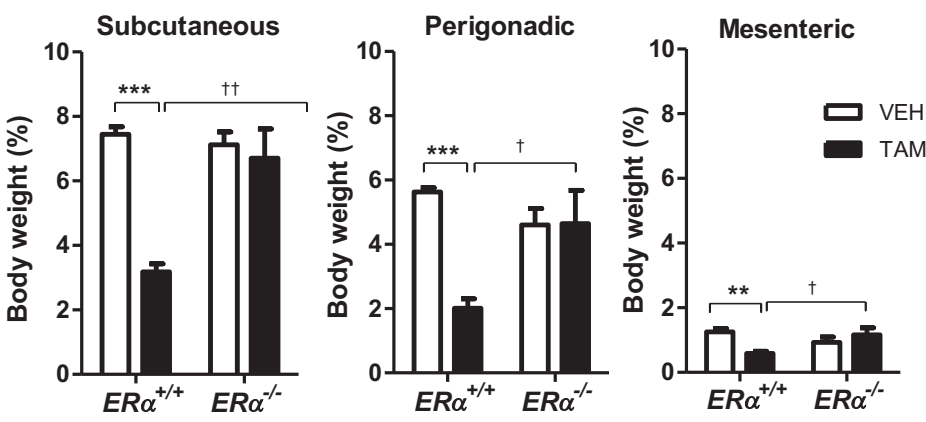

F Intrahepatic lipid content

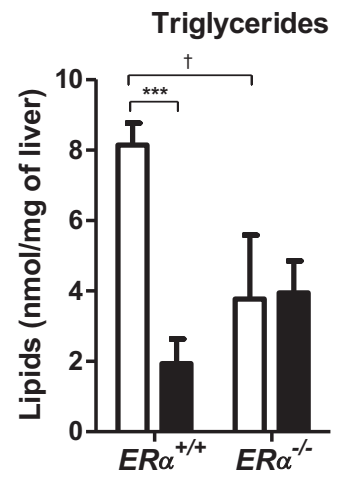

Cholesterol ester

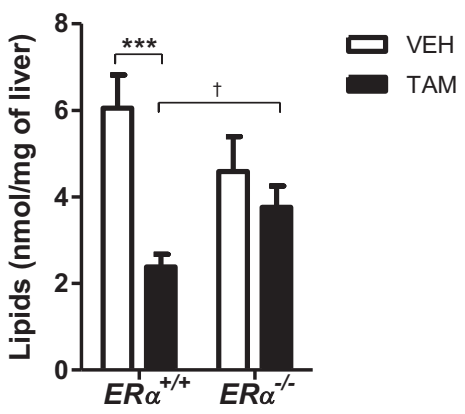

Figure 2 Metabolic protective effects of tamoxifen (TAM) require estrogen receptor $\alpha$ (ER $\alpha$ ) activation. Ovariectomized $E R \alpha^{-1-}$ female mice and their wildtype littermates $\left(E R \alpha^{+/+}\right)$were fed a high-fat diet (HFD) and concomitantly treated with TAM or vehicle (VEH) for 6 weeks. A and B: Body weight evolution (A) and final body weight gain (A) as well as food intake (B) were recorded weekly. C: Body composition was assessed by magnetic resonance imaging (EchoMRI) before sacrifice. D: Adipose tissue distribution (subcutaneous, perigonadic, and mesenteric sites) was assessed at sacrifice. E: i.p. glucose tolerance test was performed 1 week before sacrifice. F: Intrahepatic neutral lipid content was measured in liver samples after sacrifice. Data are expressed as means \pm SEM. ${ }^{*} P<0.05,{ }^{* *} P<0.01,{ }^{* * *} P<0.001$ (TAM versus VEH) ${ }^{\dagger} P<0.05,{ }^{\dagger \dagger} P<0.01$, and ${ }^{\dagger \dagger \dagger} P<0.001$ for genotype effect $\left(E R \alpha^{-/-}\right.$versus $E R \alpha^{+/+}$).

prominent role of decreased food intake, additional mechanisms could also contribute, at least in part, to the prevention of obesity and metabolic disorders by tamoxifen.

\section{Metabolic Protective Effects of Tamoxifen Require ER $\alpha$ Activation}

Beside its agonist and antagonist actions on ER $\alpha$, tamoxifen activates other targets, such as anti-estrogen-binding sites. $^{20-22}$ We then determined whether some of the tamoxifen metabolic protective effects characterized in WT mice are mediated through ER $\alpha$-independent pathways. Ovariectomized ER $\alpha$-deficient $\left(E R \alpha^{-l-}\right)$ mice and their WT littermates $\left(E R \alpha^{+/+}\right)$were fed a HFD and concomitantly treated with tamoxifen or vehicle for 6 weeks.

As expected, the effect of tamoxifen on uterine growth was abolished in $E R \alpha^{-1-}$ mice (Supplemental Figure S3A). Furthermore, although tamoxifen-treated $E R \alpha^{+/+}$littermates 

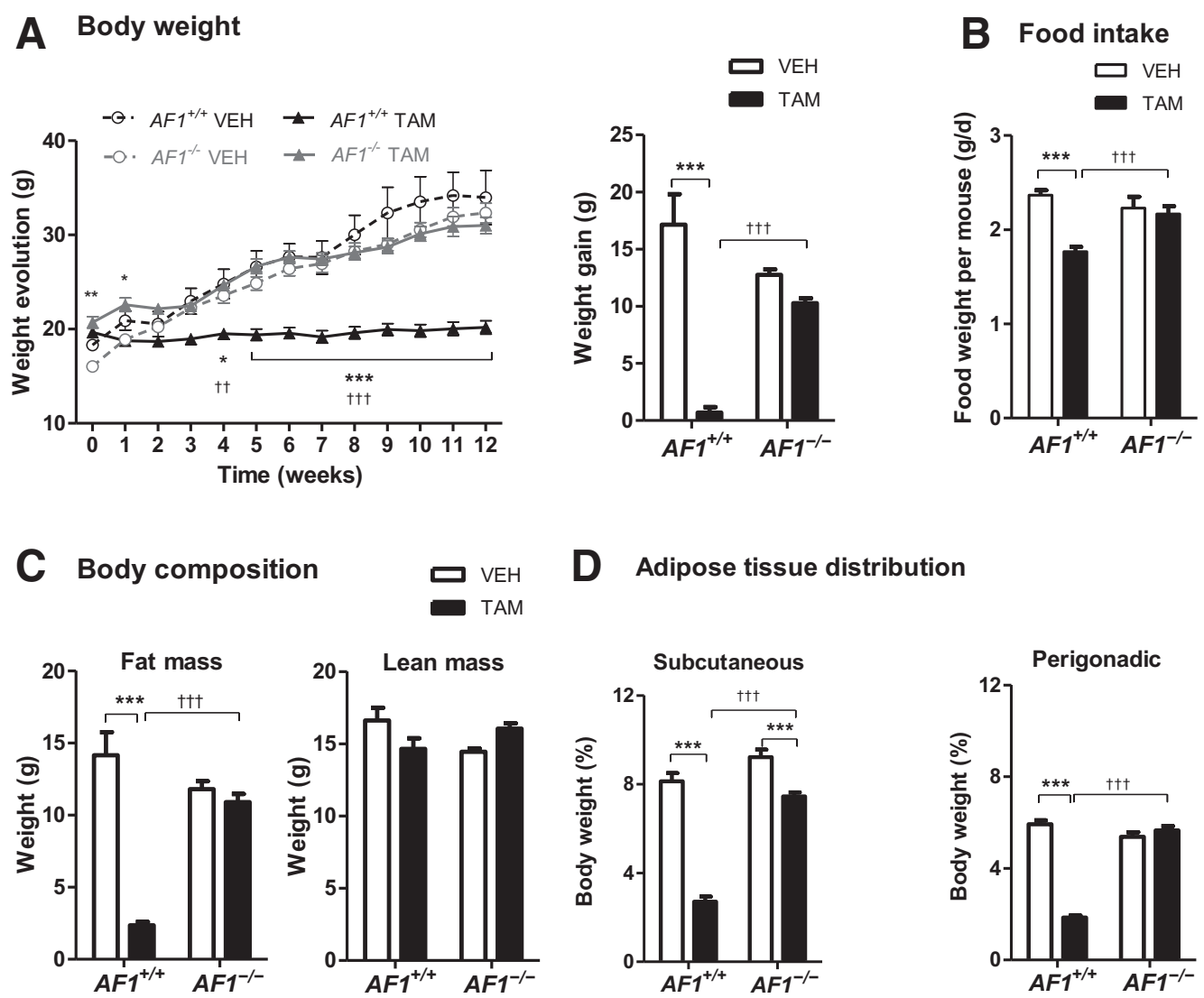

Figure 3 Estrogen receptor $\alpha$ activation function 1 (ER $\alpha$-AF1) mediates the preventive effects of tamoxifen (TAM) against high-fat diet (HFD)-induced metabolic disorders. Ovariectomized $E R \alpha-A F 1^{-/-}$female mice and their wild-type littermates $\left(E R \alpha-A F 1^{+/+}\right)$were fed a HFD and concomitantly treated with TAM or vehicle (VEH) for 12 weeks. Body weight evolution (A), final body weight gain (A), and food intake (B) were recorded weekly. C: Body composition was assessed by magnetic resonance imaging (EchoMRI) before sacrifice. D: Adipose tissue distribution (subcutaneous, perigonadic, and mesenteric sites) was assessed at sacrifice. Data are expressed as means \pm SEM. ${ }^{*} P<0.05$, ${ }^{*} P<0.01$, and ${ }^{* *} P<0.001$ (TAM versus VEH); ${ }^{\dagger \dagger} P<0.01,{ }^{\dagger \dagger \dagger} P<0.001$ for genotype effect $\left(E R \alpha-A F 1^{-/-}\right.$versus $\left.E R \alpha-A F 1^{+/+}\right)$.

were fully protected from HFD-induced metabolic disturbances, the influence of TAM on body weight and food intake (Figure 2, A-D), as well as on glucose tolerance (Figure 2E) and steatosis (Figure 2F), was totally abrogated in $E R \alpha^{-I-}$ mice. These observations thus revealed that the protective actions of tamoxifen on energy and glucose metabolism are specifically mediated through ER $\alpha$ activation.

\section{Protective Effects of Tamoxifen against HFD-Induced Metabolic Disorders Require ER $\alpha$-AF1 Activation}

Ovariectomized female mice with a specific deletion of $E R \alpha-$ $\mathrm{AF} 1\left(E R \alpha-A F 1^{-/-}\right)$and their WT littermates $\left(E R \alpha-A F 1^{+/+}\right)$ were then fed a HFD and treated with tamoxifen or vehicle for 12 weeks to determine the involvement of this activation function in the metabolic effects of the compound. As previously described, ${ }^{30}$ tamoxifen-induced uterine hypertrophy was abrogated in $E R \alpha-A F 1^{-1-}$ mice as attested by wet uterine weight (Supplemental Figure S3B). In contrast to the protective action of tamoxifen in control mice, tamoxifen-treated $E R \alpha-A F 1^{-/-}$mice were not protected from HFD-induced adiposity, and food intake was not altered by the treatment in this model (Figure 3). Likewise, prevention of HFDinduced glucose intolerance (Figure 4A), insulin resistance (Figure 4B and Table 3), and steatosis (Figure 4, C and D) by tamoxifen was totally abolished in $E R \alpha-A F 1^{-1-}$ mice. Accordingly, tamoxifen did not alter total cholesterol, highdensity lipoprotein cholesterol, and adiponectin circulating levels in $E R \alpha-A F 1^{-/}$mice, whereas tamoxifen-induced decrease in plasma resistin and leptin concentration was only attenuated (Table 3). Altogether, these data indicate that the metabolic in vivo effects of tamoxifen absolutely require the activation of ER $\alpha-\mathrm{AF} 1$.

\section{Liver Metabolic Gene Regulation by Tamoxifen Depends on ER $\alpha-A F 1$}

Because ER $\alpha-\mathrm{AF} 1$ is involved in the control of gene transcription, we next explored the influence of tamoxifen administration on hepatic gene expression, focusing on a set of 42 genes involved in hepatic lipid and glucose metabolic pathways. We first characterized tamoxifen-regulated genes in WT mice and found that 13 and 3 of 42 genes were 


\section{A Glucose tolerance tests}

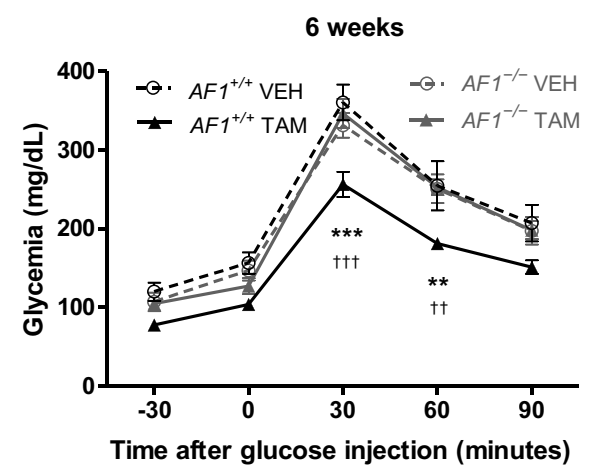

B HOMA-IR score

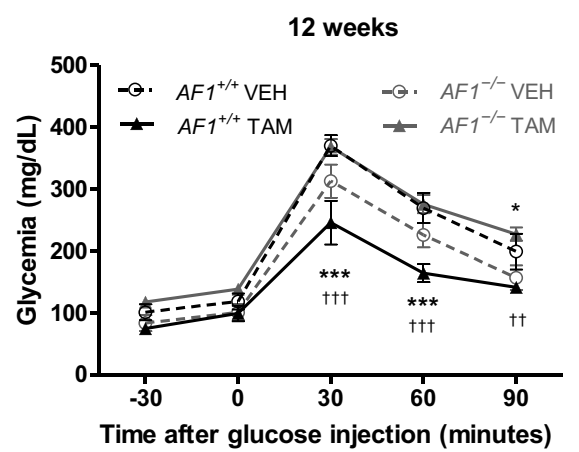

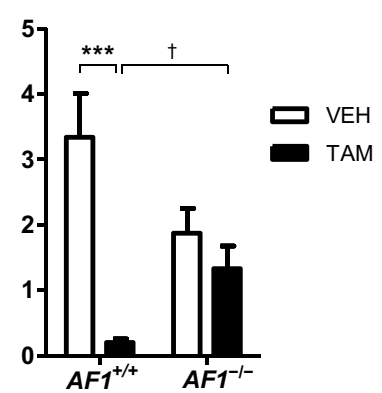

\section{Liver histology}

VEH
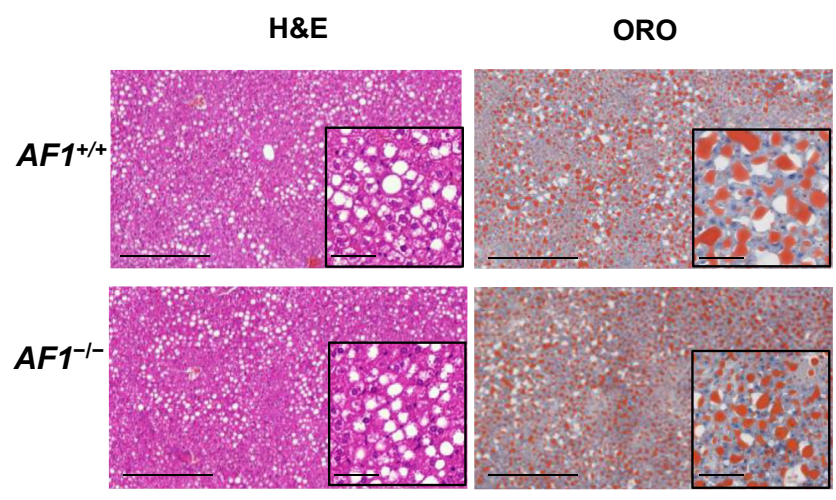

D Intrahepatic lipid content
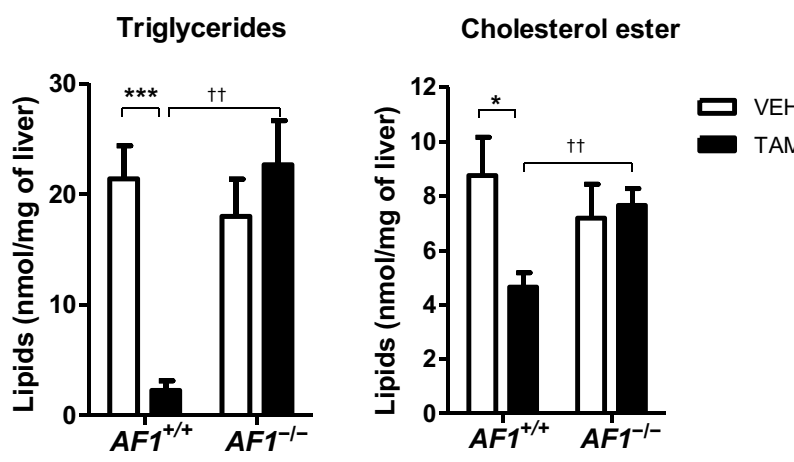

Figure 4 Protective effects of tamoxifen (TAM) on high-fat diet (HFD)induced insulin resistance and fatty liver require estrogen receptor $\alpha$ activation function 1 (ER $\alpha-A F 1)$. Ovariectomized $E R \alpha-A F 1^{-/-}$female mice and their wild-type littermates $\left(E R \alpha-A F 1^{+/+}\right)$were fed a HFD and concomitantly AM treated with TAM or vehicle (VEH) for 12 weeks. A: i.p. glucose tolerance tests were performed after 6 and 12 weeks of HFD. B: Homeostatic model assessment of insulin resistance (HOMA-IR) score was calculated before sacrifice. C: Liver histology. Representative images of hematoxylin and eosin (H\&E) and Oil Red 0 (ORO) staining on liver sections. Insets show higher magnification. D: Intrahepatic neutral lipid content was assessed in liver samples after sacrifice. Data are expressed as means \pm SEM. ${ }^{*} P<0.05$, ${ }^{*} * P<0.01,{ }^{* * *} P<0.001$ (TAM versus VEH); ${ }^{\dagger} P<0.05,{ }^{\dagger \dagger} P<0.01$, and ${ }^{+\dagger \dagger} P<0.001$ for genotype effect $\left(E R \alpha-A F 1^{-/-}\right.$versus $\left.E R \alpha-A F 1^{+/+}\right)$. Scale bars $=$ $100 \mu \mathrm{m}$ (C); $50 \mu \mathrm{m}$ (C, insets). characterized by a significant down-regulation or upregulation, respectively, compared with vehicle-treated mice (Table 4). Down-regulated genes are involved in cholesterol metabolism and lipoprotein assembly (Hmgcr, Apoal, and Pltp), glucose metabolism (Gck, Slc2a4), fatty acid oxidation (Acacb), lipid synthesis (Scdl, Fasn, Ppard, Pemt, and Plin2), and lipid transport (Fabpl). Inversely, tamoxifen induced an up-regulation of Cyp7al, which is involved in cholesterol degradation. We also observed a significant down-regulation of the gene coding for the hepatokine Fgf21 and an up-regulation of genes coding for the hepatokine Gdf15 and for Lepr, the latter being known to be also induced by E2. ${ }^{31}$

Using liver of $E R \alpha-A F 1^{-1-}$ mice and their $E R \alpha-A F 1^{+/+}$ littermates, we then explored the mRNA expression level of the 23 of the 42 genes whose regulation by tamoxifen was higher than 30\% in WT mice. Among them, Fgf21, Ppard, Plin2, Hmgcr, Apoal, and Fabpl were no longer regulated in $E R \alpha-A F 1^{+/+}$littermates, whereas Sirtl, Apoa4, Acoxl, Pparg, Pckl, and Pnpla2 were modulated by tamoxifen treatment (Figure 5). However, all tamoxifen-regulated genes were dependent on $\mathrm{ER} \alpha-\mathrm{AF} 1$ activation. Indeed, both 
Table 3 Influence of TAM on Plasma Parameters in High-Fat Diet-Fed $E R \alpha-A F 1^{-/-}$Mice

\begin{tabular}{|c|c|c|c|c|}
\hline \multirow[b]{2}{*}{ Parameter } & \multicolumn{2}{|l|}{$E R \alpha-A F 1^{+/+}$} & \multicolumn{2}{|l|}{$E R \alpha-A F 1^{-/-}$} \\
\hline & VEH & TAM & VEH & TAM \\
\hline ALT, IU/L & $71 \pm 21$ & $46 \pm 26$ & $71 \pm 29$ & $45 \pm 11$ \\
\hline $\mathrm{HDL}-\mathrm{C}, \mathrm{mmol} / \mathrm{L}$ & $1.84 \pm 0.37$ & $1.08 \pm 0.10 * *$ & $2.06 \pm 0.13$ & $1.95 \pm 0.13^{\dagger \dagger \dagger}$ \\
\hline LDL-C, mmol/L & $0.55 \pm 0.06$ & $0.45 \pm 0.02$ & $0.56 \pm 0.04$ & $0.57 \pm 0.07$ \\
\hline Triglycerides, mmol/L & $1.05 \pm 0.19$ & $0.75 \pm 0.06^{*}$ & $1.08 \pm 0.07$ & $0.79 \pm 0.11^{*}$ \\
\hline Resistin, $\mathrm{ng} / \mathrm{mL}$ & $5.56 \pm 0.45$ & $2.17 \pm 0.51 * * *$ & $5.94 \pm 0.64$ & $3.87 \pm 1.14^{* * \dagger}$ \\
\hline Adiponectin, ng/mL & $7.54 \pm 1.11$ & $4.89 \pm 0.30^{* *}$ & $6.87 \pm 0.48$ & $6.44 \pm 0.89^{\dagger}$ \\
\hline Leptin, $\mathrm{ng} / \mathrm{mL}$ & $30.2 \pm 7.0$ & $1.6 \pm 0.3^{* * *}$ & $25.3 \pm 1.9$ & $13.6 \pm 2.6^{* * \dagger \dagger \dagger}$ \\
\hline $\mathrm{FGF} 21, \mathrm{pg} / \mathrm{mL}$ & $136 \pm 136$ & $3 \pm 3$ & $87 \pm 133$ & $51 \pm 51$ \\
\hline
\end{tabular}

Blood samples from $E R \alpha-A F 1^{+/+}$and $E R \alpha-A F 1^{-/-}$female mice fed a high-fat diet for 12 weeks and concomitantly treated with TAM or VEH were collected at sacrifice. Data are expressed as means \pm SEM.

${ }^{*} P<0.05,{ }^{*} P<0.01$, and ${ }^{*} * P<0.001$ (TAM versus VEH).

${ }^{\dagger} P<0.05,{ }^{\dagger \dagger} P<0.001$ for genotype effect $\left(E R \alpha-A F 1^{-/-}\right.$versus $\left.E R \alpha-A F 1^{+/+}\right)$.

ALT, alanine aminotransferase; FFA, free fatty acids; FGF21, fibroblast growth factor 21; HDL-C, high-density lipoprotein cholesterol; LDL-C, low density lipoprotein cholesterol; TAM, tamoxifen; VEH, vehicle.

up- and down-regulations observed in control mice were abrogated in $E R \alpha-A F 1^{-/-}$mice (Figure 5). In a few cases (Cyp7al, Fabpl, Apoal, Fgf21, and Plin2), tamoxifeninduced gene regulation was even inverted in $E R \alpha-A F 1^{-/-}$ mice. However, the present data indicate that the regulation of most of hepatic metabolic genes by tamoxifen depends on the selective activation of ER $\alpha$-AF1.

Finally, we assessed the expression of selected genes involved in lipid and glucose metabolism in subcutaneous white adipose tissue. Although Srebf1, Plin2, Fabp4, and Acaca gene expression levels were unchanged, the expression of Pparg, Lep, Fasn, and Scl2a4 involved in de novo lipogenesis and glucose uptake were significantly decreased by tamoxifen treatment in tamoxifen-treated $E R \alpha-A F 1^{+/+}$ mice (Supplemental Figure S4) in perfect agreement with the decrease in adipose tissue weight pads. Tamoxifeninduced regulation was all abrogated in $E R \alpha-A F 1^{-1-}$ mice, thus revealing in another tissue that tamoxifen regulates metabolic genes in an AF1-dependent manner.

\section{Discussion}

We report for the first time in vivo that tamoxifen exerts a significant preventive effect against HFD-induced obesity, steatosis, insulin resistance, and glucose intolerance through the selective activation of ER $\alpha$-AF1. Furthermore, we recently reported that metabolic protection conferred by E2 administration in the same experimental conditions requires $\mathrm{ER} \alpha-\mathrm{AF} 2$, whereas $\mathrm{ER} \alpha-\mathrm{AF} 1$ is dispensable, ${ }^{15}$ yet the present data indicate that a full redundancy between ER $\alpha$ $\mathrm{AF} 1$ and ER $\alpha-\mathrm{AF} 2$ characterizes the overall protective metabolic action of ER $\alpha$. However, according to the notion that the prominent role of either ER $\alpha-\mathrm{AF} 1$ or $\mathrm{ER} \alpha-\mathrm{AF} 2$ is probably tissue specific in vivo, we cannot exclude from our study that E2 and tamoxifen exert their respective protection by targeting different cell types and/or metabolic pathways. Nevertheless, this observation is in striking contrast with the involvement of both in breast cancer proliferation, as concluded from in vitro studies and experiments that address the role of an isoform deficient in ER $\alpha$-AF1. ${ }^{8-10}$

Providing important new insights in understanding the mechanisms of ER $\alpha$ activation, high-resolution X-ray crystallography has allowed a precise definition of the structure and conformation of the DNA-binding domain and the ligandbinding domain. In particular, the most $\mathrm{C}$-terminal helical segment (helix 12) is the major architectural feature associated with $\mathrm{ER} \alpha-\mathrm{AF} 2$ function, and through allosteric mechanisms, it can undergo dramatic position shifts according to the nature of the ligand that is bound somewhat distant in the ligandbinding pocket. In contrast, as specified in the introduction, $\mathrm{ER} \alpha-\mathrm{AF} 1$ is located in the intrinsically disordered $\mathrm{N}$-terminal domain that has not yet been characterized by crystallization and high-resolution structure determinations. ${ }^{5}$ The mechanisms of ER $\alpha$-AF1 activation by estrogens or tamoxifen thus remain elusive, as well as the mechanisms leading to ligandindependent $\mathrm{ER} \alpha$ activation. Indeed, ligands of several growth factor receptors, including insulin-like growth factor 1 , epidermal growth factor, or fibroblast growth factor 2 , activate $\mathrm{ER} \alpha-\mathrm{AF} 1$ through the phosphorylation of several key amino acids located in the B domain. These interactions result in ER-mediated induction of gene transcription independently of the binding of an estrogenic ligand. Although the analysis of this level of complexity cannot be totally explained by in vivo studies, it underlines that ER $\alpha-\mathrm{AF} 1$ is at the crossroad of numerous endocrine and growth factor pathways that could be involved in the ER $\alpha$-mediated beneficial metabolic effects of tamoxifen.

We considered tamoxifen as an interesting pharmacologic tool for its ability to selectively activate ER $\alpha$-AF1. Indeed, although tamoxifen inhibits ER $\alpha$-mediated effects only through $\mathrm{ER} \alpha-\mathrm{AF} 2$ antagonism, ${ }^{32}$ its agonistic activity is 
Table 4 Influence of Tamoxifen on the Expression of 42 Hepatic Genes Involved in Lipid and Glucose Metabolism in Wild-Type Mice Fed with a High-Fat Diet for 12 Weeks

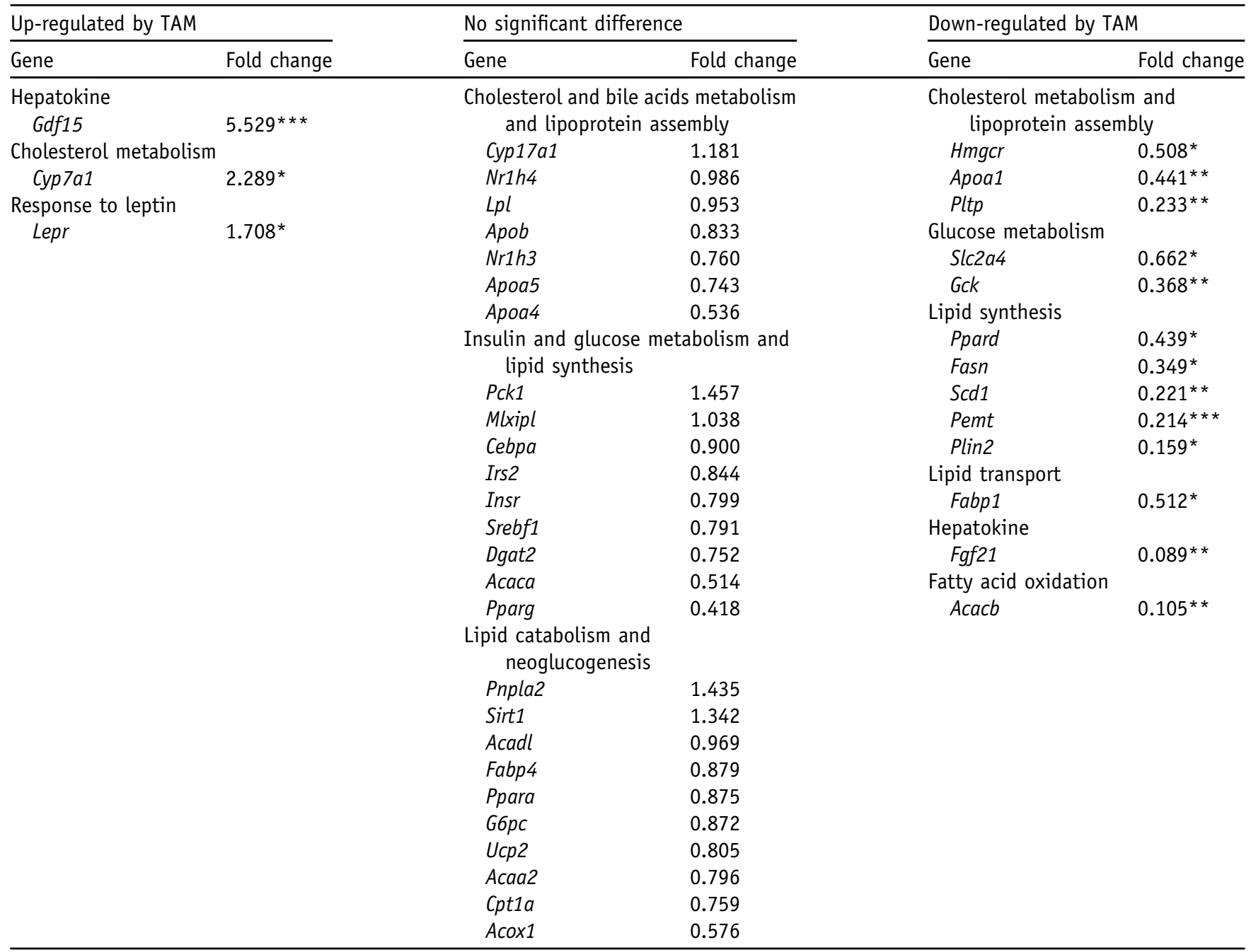

mRNA expression levels were determined by real-time quantitative PCR. Data are expressed as means.

${ }^{*} P<0.05,{ }^{* *} P<0.01$, and ${ }^{* * *} P<0.001$ (TAM versus VEH).

TAM, tamoxifen; VEH, vehicle.

mediated through ER $\alpha$-AF1 activation, which depends on cell type and promoter context. ${ }^{17}$ Accordingly, besides its antagonist actions widely used to reduce the local or distant recurrence of breast cancer in patients with ER-positive tumors, ${ }^{33}$ tamoxifen also acts as an agonist in other tissues, such as the uterus, ${ }^{7}$ as confirmed in the present study, or bones, where it confers osteoporosis prevention. ${ }^{34}$ Furthermore, although deleterious on the risk of thromboembolism on the venous side as described with estrogens, tamoxifen prevents arteries from the development of atheroma lesions, ${ }^{30,35,36}$ and we recently found that this atheroprotective action entirely depends on ER $\alpha$-AF1 activation. ${ }^{30}$

The metabolic effects of tamoxifen are still not well characterized, particularly at a molecular level. In ovariectomized female rodents fed a chow diet, long-term or shortterm tamoxifen administrations prevent body weight gain and fat mass accumulation..$^{18,19,37,38}$ In such animal models, tamoxifen also improved plasma lipid profile ${ }^{38}$ and lowered plasma glucose levels. ${ }^{38}$ In humans, the influence of tamoxifen on body weight is more controversial, ${ }^{39}$ with some studies reporting no effect in overweight or obese postmenopausal women receiving tamoxifen for breast cancer, ${ }^{40}$ and others reporting that tamoxifen decreases body mass index in obese women with ${ }^{41}$ or without breast cancer, ${ }^{37}$ the latter study being the only one comparing tamoxifen with a placebo group.

Importantly, tamoxifen has also been reported for a long time to promote steatosis, although the overall analysis of clinical observations remains uneasy because of heterogeneity in the populations included in placebo-controlled trials $^{42,43}$ and observational clinical reports ${ }^{4,45}$ (menopausal status, initial anthropometric and metabolic status, context of breast cancer with major potential interferences of aggressive chemotherapies). Moreover, the incidence of tamoxifen-induced steatosis appears to be very low $(0.37$ per 100 women per year in tamoxifen-treated women versus 


\section{De novo lipogenesis and lipid synthesis}
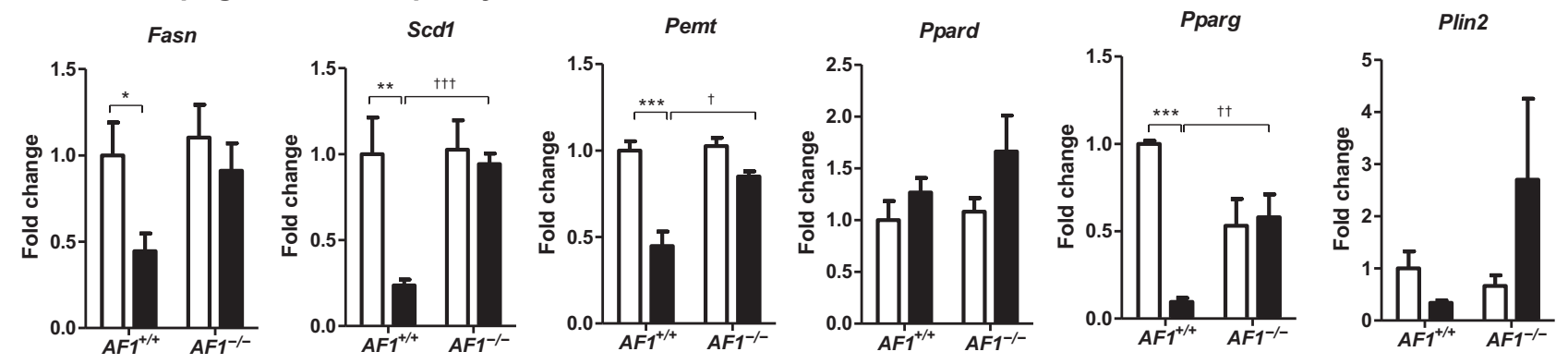

\section{Cholesterol metabolism and lipoprotein assembly}
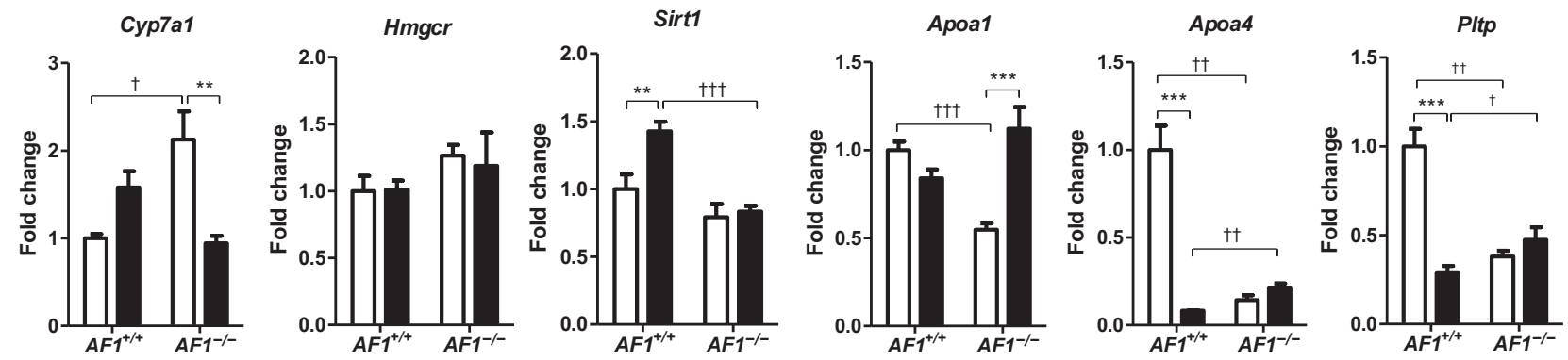

\section{Lipid catabolism}
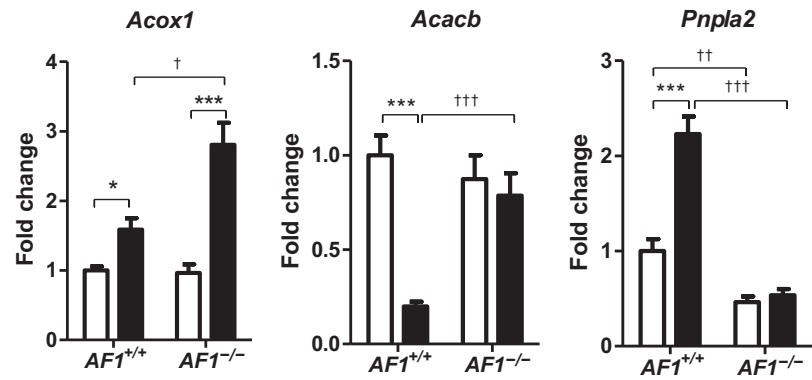

\section{Lipid transport}

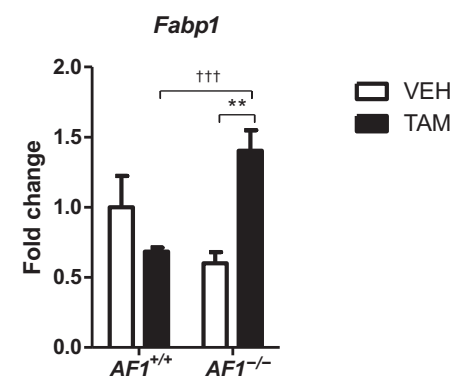

Hepatokines and cell surface receptor

\section{Glucose metabolism}
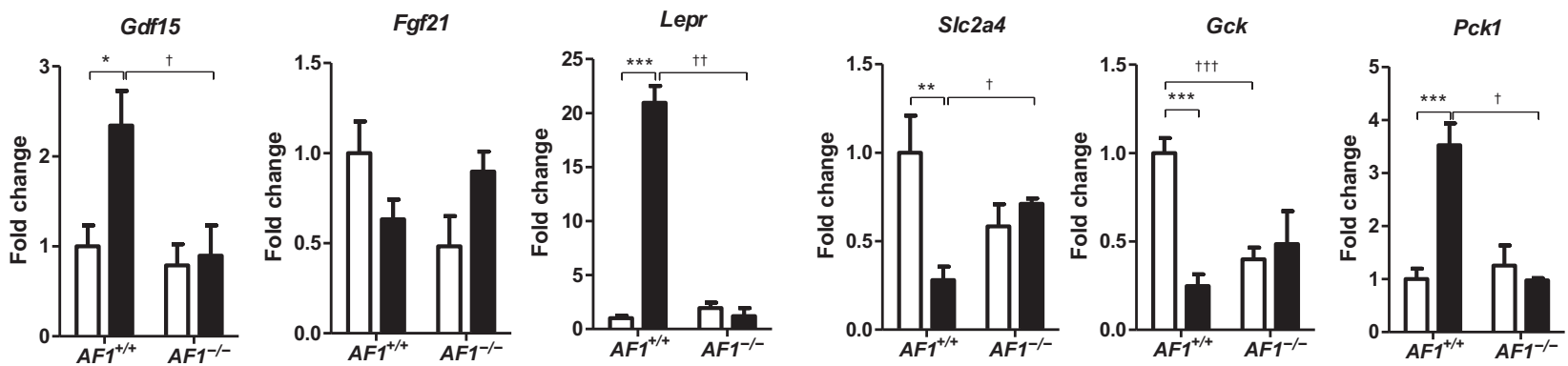

Figure 5 Liver metabolic gene regulation by tamoxifen (TAM) depends on estrogen receptor $\alpha$ activation function 1 (ER $\alpha$-AF1). The 23 of 42 mRNA hepatic expression levels of metabolic genes whose regulation by TAM was higher than $30 \%$ in wild-type mice (Table 3 ) were analyzed by real-time quantitative PCR in the liver of ovariectomized $E R \alpha-A F 1^{-/-}$mice and their wild-type littermates $\left(E R \alpha-A F 1^{+/+}\right)$fed a high-fat diet (HFD) and concomitantly treated with TAM or vehicle (VEH) for 12 weeks. Data are expressed as means \pm SEM. ${ }^{*} P<0.05,{ }^{*} * P<0.01$, and ${ }^{* * *} P<0.001$ (TAM versus VEH); ${ }^{\dagger} P<0.05,{ }^{\dagger \dagger} P<0.01$, and ${ }^{\dagger \dagger} P<0.001$ for genotype effect $\left(E R \alpha-A F 1^{-/-}\right.$versus $\left.E R \alpha-A F 1^{+/+}\right)$.

0.19 per 100 women per year in untreated women) and significantly correlated with preexisting conditions of fatty liver disease and/or metabolic risk factors. ${ }^{43,46,47}$ Furthermore, animal studies led to controversial results. Although some of them reported a steatogenic effect of tamoxifen in rodents on a chow diet, either in male rats or mice administered low doses through the s.c. route $(0.5 \mathrm{mg} / \mathrm{kg} / \mathrm{d}$ for 5 days $)^{48,49}$ or in female rats receiving high doses orally 
(20 to $40 \mathrm{mg} / \mathrm{kg} / \mathrm{d}$ for 14 to 28 days), ${ }^{50,51}$ other studies suggested a protective effect of low-dose tamoxifen $(1 \mathrm{~g} / \mathrm{kg} / \mathrm{d}$ i.p. administered for 5 days) against HFD-induced steatosis or drug-induced hepatotoxicity in female mice. ${ }^{52,53}$ Noteworthy, the design of these previous studies ${ }^{52,53}$ did not include orchidectomy or ovariectomy before tamoxifen administration, a major difference with our experimental settings.

In the present study, gene expression analyses indicate that hepatic genes related to de novo lipogenesis are strongly decreased by tamoxifen treatment in WT mice and genes involved in glucose and cholesterol metabolism and lipoprotein assembly. Moreover, genes encoding proteinregulating fatty acids and triglycerides degradation have an increased expression. Altogether, these data indicate that tamoxifen treatment induces a significant decrease in lipid synthesis and an increase in lipid catabolism in the liver of WT mice. Interestingly, because the crucial role of interorgan dialogues is now well recognized in the pathophysiology of insulin resistance and nonalcoholic fatty liver disease, hepatic metabolic regulations observed in tamoxifen-treated mice could be closely linked to TAM effects on other tissular targets. Because free fatty acids produced by lipolysis in white adipose tissue are a critical driver of liver steatosis and a decrease in free fatty acid plasma levels was observed in tamoxifen-treated WT mice, we focused our interest on this tissue. The results reveal a tamoxifen-induced decrease in the expression of genes involved in de novo lipogenesis and glucose uptake in white adipose tissue, suggesting that several tissues could contribute to tamoxifen-mediated protection from metabolic disturbances in HFD-fed mice.

The present data thus indicate the capacity of tamoxifen to prevent the occurrence of obesity, steatosis, dyslipidemia, and glucose intolerance in ovariectomized mice exposed to a nutritional stress. Obviously, the significant reduction in food intake observed in tamoxifen-treated WT mice must be taken into account to adequately interpret the overall beneficial action of the compound. Indeed, the decrease in physical activity level and in energy expenditure observed in tamoxifen-treated mice certainly arises from this suppressing effect on food consumption. Interestingly, such an anorexigenic effect of tamoxifen has already been reported in rats ${ }^{18,19,37,38}$ and attributed to fatty acid synthase inhibition in the ventromedial nucleus of the hypothalamus, leading to accumulation of malonyl-CoA. ${ }^{37}$ However, although the results obtained from our pair-feeding experiment have to be confirmed during a longer period and in various nutritional settings, they suggest that the regulation of energy homeostasis by tamoxifen probably combines specific effects at the level of the central nervous system and on peripheral tissues, such as the liver or adipose tissue. From our data, it is also possible to speculate that peripheral signals participate toward the tamoxifen-induced reduction in food intake. Indeed, gene expression profile analyses revealed a strong tamoxifen-induced increase in Gdf15 hepatic expression, a hepatokine known to decrease food intake through a direct central action on appetite control in the hypothalamus. ${ }^{54}$

As mentioned above, tamoxifen has been reported to involve other molecular targets than $\mathrm{ER} \alpha{ }^{20}$ such as the inhibition of cholesterol esterification, which could contribute to its atheroprotective and antitumoral effects, ${ }^{21}$ or the interaction with the anti-estrogen-binding sites that leads to the intracellular accumulation of oxysterols and thus to cancer cell death. ${ }^{22}$ Other actions have also been reported, such as scavenging peroxyl radicals, preventing apoptosis, ${ }^{5}$ stabilizing biological membranes, ${ }^{56}$ and inhibiting fibrosis. ${ }^{57}$ However, the use of the transgenic $E R \alpha^{-1-}$ and $E R \alpha-A F 1^{-/-}$mouse models allowed us to find that the anorexigen and all of the protective metabolic actions of tamoxifen absolutely require ER $\alpha$ and, even more specifically, ER $\alpha$-AF1 activation. Further illustrating the pivotal role of ER $\alpha$-AF1, we found that tamoxifen-associated gene regulation of several pathways involved in lipid and glucose metabolism in the liver was totally abrogated in HFD-fed $E R \alpha-A F 1^{-1-}$ mice. Thus, although we cannot definitely exclude that tamoxifen is able to activate other molecular targets in vivo, our study allows us to conclude that ER $\alpha$ AF1 is absolutely required for the metabolic actions of tamoxifen, as previously reported for its atheroprotective effect. $^{30}$

In conclusion, combined with our previous study of the mechanisms mediating E2 metabolic effects, ${ }^{15}$ the present data indicate that the selective activation of ER $\alpha$-AF1 or $\mathrm{ER} \alpha-\mathrm{AF} 2$ is sufficient to elicit a full prevention of obesity, nonalcoholic fatty liver disease, and type 2 diabetes in mice receiving a HFD. Thus, at variance with other steroid receptors for which AF1 plays a prominent transcriptional role, partial or full redundancy appears to exist between $\mathrm{ER} \alpha-\mathrm{AF} 1$ or $\mathrm{ER} \alpha-\mathrm{AF} 2$ to mediate protective actions on energy homeostasis, as well as on lipid and glucose metabolisms (present work), but also on bone ${ }^{11}$ and the arterial wall. $^{12,13,30}$ This finding strikingly contrasts with the suggested requirement of both $\mathrm{ER} \alpha$-AFs in breast cancer proliferation, reinforcing the therapeutic interest for selective estrogen receptor modulation. Altogether, the present study first suggests that the metabolic effects of tamoxifen in women deserves to be cautiously reconsidered, then opens new perspectives for the treatment of obesity-related complications toward a pharmacologic strategy eliciting selective ER $\alpha$-AF1 activation.

\section{Acknowledgments}

We thank Marie-Cécile Valéra, Françoise Lenfant, Marc Poirot, Henrick Laurell, and Marine Adlanmerini for helpful discussions; Frédéric Boudou for skillful technical assistance; the ANEXPLO-GENOTOUL platform (INSERM UMR1048, Toulouse, France) for excellent technical assistance in animal functional experimentation as well as in 
biochemical and magnetic resonance imaging (EchoMRI) analyses (Cédric Baudelin, Aurore Desquesnes, Sophie Le Gonidec); the histology platform (Lucie Fontaine, Isabelle Bleuart, and Isabelle Pardo); the GeT-TQ Genopole platform (INSERM UMR1048, Toulouse, France) for technical contribution to real-time quantitative PCR experiments (Frédéric Martins, Jean-José Maoret); the MetaToulLIPIDOMIQUE platform (INSERM UMR1048, Toulouse, France) for intrahepatic lipid content determinations (Justine Bertrand-Michel); Sébastien Déjean for his help in statistical analyses; and Prof. Pierre Chambon (IGBMC, Strasbourg, France) for mice strains.

P.G. is the guarantor of this work and, as such, had full access to all the data and takes responsibility for the integrity of the data and the accuracy of the data analysis.

\section{Supplemental Data}

Supplemental material for this article can be found at http://dx.doi.org/10.1016/j.ajpath.2017.02.013.

\section{References}

1. Hevener AL, Clegg DJ, Mauvais-Jarvis F: Impaired estrogen receptor action in the pathogenesis of the metabolic syndrome. Mol Cell Endocrinol 2015, 418 Pt 3:306-321

2. Metzger D, Ali S, Bornert JM, Chambon P: Characterization of the amino-terminal transcriptional activation function of the human estrogen receptor in animal and yeast cells. J Biol Chem 1995, 270: 9535-9542

3. Smith CL, O'Malley BW: Coregulator function: a key to understanding tissue specificity of selective receptor modulators. Endocr Rev 2004, 25:45-71

4. Lonard DM, O'Malley BW: Nuclear receptor coregulators: judges, juries, and executioners of cellular regulation. Mol Cell 2007, 27: 691-700

5. Simons SS Jr, Edwards DP, Kumar R: Minireview: dynamic structures of nuclear hormone receptors: new promises and challenges. Mol Endocrinol 2014, 28:173-182

6. Merot Y, Metivier R, Penot G, Manu D, Saligaut C, Gannon F, Pakdel F, Kah O, Flouriot G: The relative contribution exerted by AF1 and AF-2 transactivation functions in estrogen receptor alpha transcriptional activity depends upon the differentiation stage of the cell. J Biol Chem 2004, 279:26184-26191

7. Abot A, Fontaine C, Raymond-Letron I, Flouriot G, Adlanmerini M, Buscato M, Otto C, Berges H, Laurell H, Gourdy P, Lenfant F, Arnal JF: The AF-1 activation function of estrogen receptor alpha is necessary and sufficient for uterine epithelial cell proliferation in vivo. Endocrinology 2013, 154:2222-2233

8. Carreau C, Flouriot G, Bennetau-Pelissero C, Potier M: Respective contribution exerted by $\mathrm{AF}-1$ and $\mathrm{AF}-2$ transactivation functions in estrogen receptor alpha induced transcriptional activity by isoflavones and equol: consequence on breast cancer cell proliferation. Mol Nutr Food Res 2009, 53:652-658

9. Penot G, Le Peron C, Merot Y, Grimaud-Fanouillere E, Ferriere F, Boujrad N, Kah O, Saligaut C, Ducouret B, Metivier R, Flouriot G: The human estrogen receptor-alpha isoform hERalpha46 antagonizes the proliferative influence of hERalpha66 in MCF7 breast cancer cells. Endocrinology 2005, 146:5474-5484

10. Klinge CM, Riggs KA, Wickramasinghe NS, Emberts CG, McConda DB, Barry PN, Magnusen JE: Estrogen receptor alpha 46 is reduced in tamoxifen resistant breast cancer cells and re-expression inhibits cell proliferation and estrogen receptor alpha 66-regulated target gene transcription. Mol Cell Endocrinol 2010, 323:268-276

11. Börjesson AE, Farman HH, Engdahl C, Koskela A, Sjögren K Kindblom JM, Stubelius A, Islander U, Carlsten H, Antal MC, Krust A, Chambon P, Tuukkanen J, Lagerquist MK, Windahl SH, Ohlsson C: The role of activation functions 1 and 2 of estrogen receptor- $\alpha$ for the effects of estradiol and selective estrogen receptor modulators in male mice. J Bone Miner Res 2013, 28:1117-1126

12. Billon-Gales A, Fontaine C, Filipe C, Douin-Echinard V, Fouque MJ Flouriot G, Gourdy P, Lenfant F, Laurell H, Krust A, Chambon P, Arnal JF: The transactivating function 1 of estrogen receptor \{alpha\} is dispensable for the vasculoprotective actions of 17 \{beta\}-estradiol. Proc Natl Acad Sci U S A 2009, 106:2053-2058

13. Billon-Gales A, Krust A, Fontaine C, Abot A, Flouriot G, Toutain C, Berges H, Gadeau AP, Lenfant F, Gourdy P, Chambon P, Arnal JF: Activation function $2(\mathrm{AF} 2)$ of estrogen receptor- $\{$ alpha $\}$ is required for the atheroprotective action of estradiol but not to accelerate endothelial healing. Proc Natl Acad Sci U S A 2011, 108: $13311-13316$

14. Smirnova NF, Fontaine C, Buscato M, Lupieri A, Vinel A, Valera MC, Guillaume M, Malet N, Foidart JM, Raymond-Letron I, Lenfant F, Gourdy P, Katzenellenbogen BS, Katzenellenbogen J, Laffargue M, Arnal JF: The activation function-1 of estrogen receptor alpha prevents arterial neointima development through a direct effect on smooth muscle cells. Circ Res 2015, 117:770-778

15. Handgraaf S, Riant E, Fabre A, Waget A, Burcelin R, Liere P, Krust A, Chambon P, Arnal JF, Gourdy P: Prevention of obesity and insulin resistance by estrogens requires ERalpha activation function-2 (ERalphaAF-2), whereas ERalphaAF-1 is dispensable. Diabetes 2013, 62:4098-4108

16. Early Breast Cancer Trialists' Collaborative Group: Tamoxifen for early breast cancer: an overview of the randomised trials. Lancet 1998, 351:1451-1467

17. Berry M, Metzger D, Chambon P: Role of the two activating domains of the oestrogen receptor in the cell-type and promoter-context dependent agonistic activity of the anti-oestrogen 4-hydroxytamoxifen. EMBO J 1990, 9:2811-2818

18. Wade GN, Heller HW: Tamoxifen mimics the effects of estradiol on food intake, body weight, and body composition in rats. Am J Physiol 1993, 264:R1219-R1223

19. Wallen WJ, Belanger MP, Wittnich C: Sex hormones and the selective estrogen receptor modulator tamoxifen modulate weekly body weights and food intakes in adolescent and adult rats. J Nutr 2001, 131:2351-2357

20. de Medina P, Paillasse MR, Segala G, Khallouki F, Brillouet S, Dalenc F, Courbon F, Record M, Poirot M, Silvente-Poirot S: Importance of cholesterol and oxysterols metabolism in the pharmacology of tamoxifen and other AEBS ligands. Chem Phys Lipids 2011, 164:432-437

21. de Medina P, Payre BL, Bernad J, Bosser I, Pipy B, Silvente-Poirot S, Favre G, Faye JC, Poirot M: Tamoxifen is a potent inhibitor of cholesterol esterification and prevents the formation of foam cells. J Pharmacol Exp Ther 2004, 308:1165-1173

22. Segala G, de Medina P, Iuliano L, Zerbinati C, Paillasse MR, Noguer E, Dalenc F, Payre B, Jordan VC, Record M, SilventePoirot S, Poirot M: 5,6-Epoxy-cholesterols contribute to the anticancer pharmacology of tamoxifen in breast cancer cells. Biochem Pharmacol 2013, 86:175-189

23. Ke HZ, Chen HK, Simmons HA, Qi H, Crawford DT, Pirie CM, Chidsey-Frink KL, Ma YF, Jee WS, Thompson DD: Comparative effects of droloxifene, tamoxifen, and estrogen on bone, serum cholesterol, and uterine histology in the ovariectomized rat model. Bone 1997, 20:31-39

24. Liu L, Zou P, Zheng L, Linarelli LE, Amarell S, Passaro A, Liu D, Cheng Z: Tamoxifen reduces fat mass by boosting reactive oxygen species. Cell Death Dis 2015, 6:e1586 
25. Lamas AZ, Caliman IF, Dalpiaz PL, de Melo AF Jr, Abreu GR, Lemos EM, Gouvea SA, Bissoli NS: Comparative effects of estrogen, raloxifene and tamoxifen on endothelial dysfunction, inflammatory markers and oxidative stress in ovariectomized rats. Life Sci 2015, 124:101-109

26. Grainger DJ, Witchell CM, Metcalfe JC: Tamoxifen elevates transforming growth factor-beta and suppresses diet-induced formation of lipid lesions in mouse aorta. Nat Med 1995, 1:1067-1073

27. Matic M, Bryzgalova G, Gao H, Antonson P, Humire P, Omoto Y, Portwood N, Pramfalk C, Efendic S, Berggren PO, Gustafsson JA, Dahlman-Wright K: Estrogen signalling and the metabolic syndrome: targeting the hepatic estrogen receptor alpha action. PLoS One 2013, 8:e57458

28. Bligh EG, Dyer WJ: A rapid method of total lipid extraction and purification. Can J Biochem Physiol 1959, 37:911-917

29. Barrans A, Collet X, Barbaras R, Jaspard B, Manent J, Vieu C, Chap H, Perret B: Hepatic lipase induces the formation of pre-beta 1 high density lipoprotein (HDL) from triacylglycerol-rich HDL2: a study comparing liver perfusion to in vitro incubation with lipases. J Biol Chem 1994, 269:11572-11577

30. Fontaine C, Abot A, Billon-Gales A, Flouriot G, Berges H, Grunenwald E, Vinel A, Valera MC, Gourdy P, Arnal JF: Tamoxifen elicits atheroprotection through estrogen receptor alpha AF-1 but does not accelerate reendothelialization. Am J Pathol 2013, 183:304-312

31. Bryzgalova G, Gao H, Ahren B, Zierath JR, Galuska D, Steiler TL, Dahlman-Wright K, Nilsson S, Gustafsson JA, Efendic S, Khan A: Evidence that oestrogen receptor-alpha plays an important role in the regulation of glucose homeostasis in mice: insulin sensitivity in the liver. Diabetologia 2006, 49:588-597

32. Fawell SE, White R, Hoare S, Sydenham M, Page M, Parker MG: Inhibition of estrogen receptor-DNA binding by the "pure" antiestrogen ICI 164,384 appears to be mediated by impaired receptor dimerization. Proc Natl Acad Sci U S A 1990, 87:6883-6887

33. Early Breast Cancer Trialists' Collaborative Group, Davies C, Godwin J, Gray R, Clarke M, Cutter D, Darby S, McGale P, Pan HC, Taylor C, Wang YC, Dowsett M, Ingle J, Peto R: Relevance of breast cancer hormone receptors and other factors to the efficacy of adjuvant tamoxifen: patient-level meta-analysis of randomised trials. Lancet 2011, 378:771-784

34. Love RR, Mazess RB, Barden HS, Epstein S, Newcomb PA, Jordan VC, Carbone PP, DeMets DL: Effects of tamoxifen on bone mineral density in postmenopausal women with breast cancer. N Engl J Med 1992, 326:852-856

35. Clarke SC, Schofield PM, Grace AA, Metcalfe JC, Kirschenlohr HL: Tamoxifen effects on endothelial function and cardiovascular risk factors in men with advanced atherosclerosis. Circulation 2001, 103:1497-1502

36. Simon T, Boutouyrie P, Simon JM, Laloux B, Tournigand C, Tropeano AI, Laurent S, Jaillon P: Influence of tamoxifen on carotid intima-media thickness in postmenopausal women. Circulation 2002, 106:2925-2929

37. Lopez M, Lelliott CJ, Tovar S, Kimber W, Gallego R, Virtue S, Blount M, Vazquez MJ, Finer N, Powles TJ, O'Rahilly S, Saha AK, Dieguez C, Vidal-Puig AJ: Tamoxifen-induced anorexia is associated with fatty acid synthase inhibition in the ventromedial nucleus of the hypothalamus and accumulation of malonyl-CoA. Diabetes 2006, 55: $1327-1336$

38. Lampert C, Arcego DM, Laureano DP, Diehl LA, da Costa Lima IF, Krolow R, Pettenuzzo LF, Dalmaz C, Vendite D: Effect of chronic administration of tamoxifen and/or estradiol on feeding behavior, palatable food and metabolic parameters in ovariectomized rats. Physiol Behav 2013, 119:17-24

39. Sheean PM, Hoskins K, Stolley M: Body composition changes in females treated for breast cancer: a review of the evidence. Breast Cancer Res Treat 2012, 135:663-680

40. Francini G, Petrioli R, Montagnani A, Cadirni A, Campagna S, Francini E, Gonnelli S: Exemestane after tamoxifen as adjuvant hormonal therapy in postmenopausal women with breast cancer: effects on body composition and lipids. Br J Cancer 2006, 95: $153-158$

41. Wasserman L, Flatt SW, Natarajan L, Laughlin G, Matusalem M, Faerber S, Rock CL, Barrett-Connor E, Pierce JP: Correlates of obesity in postmenopausal women with breast cancer: comparison of genetic, demographic, disease-related, life history and dietary factors. Int J Obes Relat Metab Disord 2004, 28:49-56

42. Pan HJ, Chang HT, Lee CH: Association between tamoxifen treatment and the development of different stages of nonalcoholic fatty liver disease among breast cancer patients. J Formos Med Assoc 2016, 115:411-417

43. Bruno S, Maisonneuve P, Castellana P, Rotmensz N, Rossi S, Maggioni M, Persico M, Colombo A, Monasterolo F, CasadeiGiunchi D, Desiderio F, Stroffolini T, Sacchini V, Decensi A, Veronesi U: Incidence and risk factors for non-alcoholic steatohepatitis: prospective study of 5408 women enrolled in Italian tamoxifen chemoprevention trial. BMJ 2005, 330:932

44. Saphner T, Triest-Robertson S, Li H, Holzman P: The association of nonalcoholic steatohepatitis and tamoxifen in patients with breast cancer. Cancer 2009, 115:3189-3195

45. Pinto HC, Baptista A, Camilo ME, de Costa EB, Valente A, de Moura MC: Tamoxifen-associated steatohepatitis-report of three cases. J Hepatol 1995, 23:95-97

46. Elefsiniotis IS, Pantazis KD, Ilias A, Pallis L, Mariolis A, Glynou I, Kada H, Moulakakis A: Tamoxifen induced hepatotoxicity in breast cancer patients with pre-existing liver steatosis: the role of glucose intolerance. Eur J Gastroenterol Hepatol 2004, 16:593-598

47. Fromenty B: Drug-induced liver injury in obesity. J Hepatol 2013, $58: 824-826$

48. Lelliott CJ, Lopez M, Curtis RK, Parker N, Laudes M, Yeo G, Jimenez-Linan M, Grosse J, Saha AK, Wiggins D, Hauton D, Brand MD, O'Rahilly S, Griffin JL, Gibbons GF, Vidal-Puig A: Transcript and metabolite analysis of the effects of tamoxifen in rat liver reveals inhibition of fatty acid synthesis in the presence of hepatic steatosis. FASEB J 2005, 19:1108-1119

49. Cole LK, Jacobs RL, Vance DE: Tamoxifen induces triacylglycerol accumulation in the mouse liver by activation of fatty acid synthesis. Hepatology 2010, 52:1258-1265

50. Gudbrandsen OA, Rost TH, Berge RK: Causes and prevention of tamoxifen-induced accumulation of triacylglycerol in rat liver. J Lipid Res 2006, 47:2223-2232

51. Jena SK, Suresh S, Sangamwar AT: Modulation of tamoxifeninduced hepatotoxicity by tamoxifen-phospholipid complex. J Pharm Pharmacol 2015, 67:1198-1206

52. Miyashita T, Toyoda Y, Tsuneyama K, Fukami T, Nakajima M, Yokoi T: Hepatoprotective effect of tamoxifen on steatosis and non-alcoholic steatohepatitis in mouse models. J Toxicol Sci 2012, 37:931-942

53. Yoshikawa Y, Miyashita T, Higuchi S, Tsuneyama K, Endo S, Tsukui T, Toyoda Y, Fukami T, Nakajima M, Yokoi T: Mechanisms of the hepatoprotective effects of tamoxifen against drug-induced and chemical-induced acute liver injuries. Toxicol Appl Pharmacol 2012, 264:42-50

54. Johnen H, Lin S, Kuffner T, Brown DA, Tsai VW, Bauskin AR, Wu L, Pankhurst G, Jiang L, Junankar S, Hunter M, Fairlie WD, Lee NJ, Enriquez RF, Baldock PA, Corey E, Apple FS, Murakami MM, Lin EJ, Wang C, During MJ, Sainsbury A, Herzog H, Breit SN: Tumor-induced anorexia and weight loss are mediated by the TGF-beta superfamily cytokine MIC-1. Nat Med 2007, 13:1333-1340

55. Custodio JB, Moreno AJ, Wallace KB: Tamoxifen inhibits induction of the mitochondrial permeability transition by $\mathrm{Ca} 2+$ and inorganic phosphate. Toxicol Appl Pharmacol 1998, 152:10-17

56. Koot RW, Amelink GJ, Blankenstein MA, Bar PR: Tamoxifen and oestrogen both protect the rat muscle against physiological damage. J Steroid Biochem Mol Biol 1991, 40:689-695

57. Kuhn MA, Wang X, Payne WG, Ko F, Robson MC: Tamoxifen decreases fibroblast function and downregulates TGF(beta2) in dupuytren's affected palmar fascia. J Surg Res 2002, 103:146-152 